\title{
SPATIAL AND TEMPORAL VARIATION IN PRODUCTIVITY, SPECIES DIVERSITY, AND PIGMENT DIVERSITY OF PERIPHYTON IN A STREAM RECEIVING DOMESTIC AND OIL REFINERY EFFLUENTS
}

\author{
By \\ JAMES MICKEY COOPER \\ Bachelor of Science \\ East Central State College \\ Ada, Oklahoma \\ 1962 \\ Master of Science \\ Oklahoma State University \\ St1llwater, Oklahoma \\ 1965
}

Submitted to the Faculty of the Graduate College of the Oklahoma State Untversity

in partial fulf1llment of the requirements

for the Degree of

DOCTOR OF PHILOSOPHY

May, 1972 
SPATIAL AND TEMPORAL VARIATION IN PRODUCTIVITY, SPECIES DIVERSITY, AND PIGMENT DIVERSITY OF PERIPHYTON IN A STREAM RECEIVING DOMESTIC AND OIL REFINERY EFFLUENTS

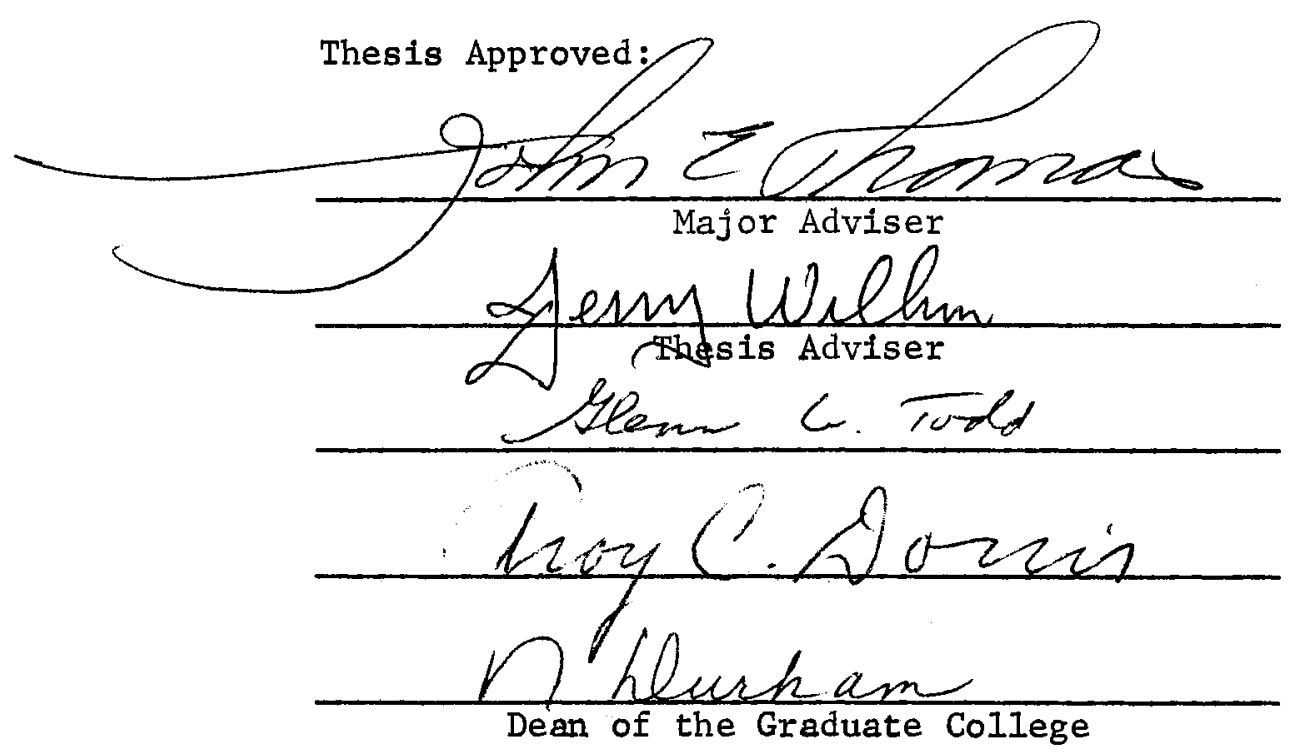




\section{PREFACE}

The objectives of the present study were to measure spatial and temporal varlation in productivity of the perfphyton communtty in a stream recelving domestic and ofl refinery effluents, to relate species diversity to levels of productivity and degrees of pollution, and to evaluate the autotrophic Index as meane of characterizing water qual1ty.

Dr. Jerry I。 W 1 lhm directed the research. Dr. John E. Thomas served as major adviser, Drs. Troy C. Dorrls, Glenn W. Todd and the late U. T. Waterfall served on the advisory committee。 Dr。Robert D。 Morrison and Mrs. Iris McPherson provided statistical and computer assistance. The help and encouragement of all these people are greatly appreclated. Special thanks are due my family, Earlene, James, and Mark for their sacrifice and encouragement during this study. 
TABLE OF CONTENTS

Chapter

Page

I. INTRODUCTION ..................

II. DESCRIPTION OF AREA . . . . . . . . . . . .

General Description ..............

Source of Waste Effluents . . . . . . . . .

Sampling Stations .............

III. METHODS ..................... 10

Sampling Times ............... 10

Phystcochemical ............... 10

Blological ................. 11

IV. RESULTS AND DISCUSSION . . . . . . . . . . 14

Physlcochemicel . . . . . . . . . . 14

Community Composition ............ 18

Blomass Accumulation ............. 18

Rat1o of Net Productivity to Blomass . . . . . 30

Sample Size ................. 31

Species Diversity ............... 35

Plgment Diversity. . . . . . ....... 39

Autotrophic Index .............. 43

v. SUMMARY ..................... 47

LITERATURE CITED . . . . . . . . . . . . . . 50 


\section{LIST OF TABLES}

Table

Page

I. Mean Seasonal Physicochemical Conditions . . . . . 15

II. Algae Identified During the Study . . . . . . . . 19

III. Slopes for the Three Growth Phases at Stations in Skeleton Creek for the Five Sampling Periods.....

IV. Comparison of $b$, Slopes with Stations Ranked from Lowest to Highest Productivity Values ........

V. Comparison of Periphyton Productivity Estimates from Various Habitats ...............

VI. Ratio of Net Productivity to Biomass in Skeleton

Creek .......................

VII. Mean Diversity Values Obtained by Pooling

Successive Samples for the Fall and

Spring ......... . . . . . . . . .

VIII. Mean Diversity Values obtained from

Independent Samples for the Fall

and Spring .....................

IX. Comparison of $\bar{d}$ Values by Duncan's New Multiple Range Test with Stations Ranked from Lowest to Highest Diversity ...............

X. Mean Seasonal Value of the Autotrophic Index for Three Seasons in Skeleton Creek, Oklahoma .......

XI. Autotrophic Index Calculated from Data in the

Literature .................... 


\section{LIST OF FIGURES}

Figure

Page

1. Skeleton Creek with Sampling Stations Indicated by Distance in Kilometers Downstream from the Confluence with Boggy Creek . . . . . . . . . . . .

2. Precipitation Amounts Recorded at Enid, Oklahoma, by the U. S. Weather Bureau . . . . . . . . . . .

3. Discontinuous Linear Regression Model Fitted to

Growth of Periphyton for the Fall . . . . . . . . .

4. Discontinuous Linear Regression Model Fitted to Growth of Periphyton for the Winter . . . . . . . . .

5. Discontinuous Linear Regression Model Fitted to Growth of Periphyton for the Spring ...........

6. Discontinuous Linear Regression Model Fitted to Growth of Perlphyton for the Summar . . . . . . . . .

7. Discontinuous Linear Regression Model Fitted to Growth of Periphyton for the Late Summer . . . . . . .

8. Longitudinal Variation of Species Diversity in Skeleton Creek for the Five Seasons . . . . . . . .

9. Temporal Variation in Pigment Diversity Ratio $D_{430} / D_{665}$ at the Four Stations in Skeleton Creek 185 the Winter Season .............

10. Temporal Variation in Pigment Diversity $D_{430} / D_{665}$ at the Four Stations in Skeleton Creek

for the Summer Season . . . . . . . . . . . . .

11. Spatial Variation in Pigment Diversity $\mathrm{D}_{430} / \mathrm{D}_{665}$ in Skeleton Creek for the Winter and Summer Seasons 
CHAPTER I

INTRODUCTION

Attached algae, perfphyton, are the most important primary producers In small, flowing streams. Perlphyton have been analyzed In terms of standing crop (Young, 1945; Blum, 1956; Cooke, 1956), specles assemblages (Yount, 1956; Castenholz, 1961; Sladeckova, 1962; Round, 1964), chlorophyll a content (McConnell and S1gler, 1959; Grezenda and Brehmer, 1960; Waters, 1961), and productivity (Wetzel, 1964, 1965; Kevern, Wilhm, and Van Dyne, 1966)。

Methods for measuring productivity of phytoplankton are not usually sultable for stream perfphyton. Carbon-14 and light and dark bottle techniques involve enclosure of the periphyton, and the restriction of water movement has been shown to affect metabolism greatly in rheophlilc periphyton (Whitford, 1960; Whitford and Shumacher, 1961). McConnell and S1gler (1959) found the method of measuring productivity by diumal oxygen curves (Odum, 1956) to be unsultable in Logan River, Utah. The most widely used method of estimating productivity of periphyton has been to place artiflclal substrata In a stream for a single extended time period (Wetzel and Westlake, 1969). This technique provides a measure of the average rate of biomass accumulation resulting from the process of colonization and ensuing growth of the attached periphyton (Wetzel, 1969). Low estimates of productivity of a well-established mat are obtalned 
when a single time period is used becauge accumulation and growth is low In the colonization phase. In addition, a single exposure period may Include part of the asymptotic level of the growth curve when increases In blomass are balanced by 10 ses due to grazing and sloughing. Thus, as the time perfod Increases, the estimated productivity decreases (Cooper and W1lhm, 1970).

Kevern, W11hm, and Van Dyne (1966) measured blomass accumulation on Plexiglas plates in a series of exposures of increasing duration (e.g., $3,6,9,12$ days, etc.) and plotted a growth curve of the standing crop of periphyton. They recognized two components in the growth curve and used a discontinuous linear regression model to distinquish between colonization and acceleration phases. The growth rate following the colonization phase was found to provide a good estimate of the productivity of a well-established periphyton mat。 Their study was terminated before the growth curve reached an asymptote. Primary productivity in streams is increased by nutrlent enrichment through organic pollution (Hynes, 1966). A stream receiving organic enrichment in the headwaters generally has high levels of nutrlents and productivity upstream and lower levels dow tream. Nutrient levels downstream are decreased by dilution and incorporation by algae.

Varlous numerical and graphic methods have been used to summarize the structure of populations of periphyton. Reporting numbers of Individuals of each species per unit area (Castenholz, 1961) or relative abundance of each species (Dickman, 1968) does not provide a single numerical value and comparisons among different studies are difficult. 
Observing total numbers of 1ndividual por unit area (Foerster and Schl1cht1ng, 1965) does not Include the relative Importance of each spacies. Graphic method have included plotting the number of species versus logarlthm of number of opecimans (Patrick, Hohn, and Wallace, 1954) and cumulative species against the log of cumulative Individual (Yount, 1956). Graph1c methods do not provlde a single numerlcal value and comparisons among studies are difficult.

A single numerical value can be obtained by using mathematical equations called diversity indices。 Several diversity indices have been proposed (Gleason, 1922; Flsher, Corbet, and W1lliams, 1943; Preston, 1948; Patten, 1962; Menh1n1ck, 1964)。Wilhm and Dorr1s (1968) have evaluated different diversity indices and concluded that the approach discussed by Margalef (1956) best summarlzes species assemblages. The equation given as a measure of specles diversity by Patten (1962) 1s,

$$
\bar{d}=\sum\left(\frac{1}{n}\right) \log _{2}\left(\frac{n}{n}\right)
$$

where $n_{1}$ is the sample estimate of number of individuals in the 1 th species and $n$ is the total number of individuals sampled. The index $\bar{d}$ possesses features which make it a reasonable measure of community structure (Wilhm and Dorris, 1968)。 The relative importance of each species in the community is expressed in a ratio representing the contribution of each specles to the total diversity. With increasing sample size, values of $\bar{d}$ increase rapidly at first and then reach an asymptote. Many rare spectes may not be taken in a sampling procedure or be overlooked in enumeration. The contribution of rare specles to 
$\bar{d}$ is small when compared to their influence on other diversity indices. The equation is dimensionless and numbers or blomass in any units can be used.

Diversity indices have been measured on benthic macrolnvertebrates (W1lhm and Dorris, 1966), phytoplankton (Patten, 1962; Staub, et al., 1970), zooplankton (Kochslek, 1970), and dlatoms (Patrlck, 1968). However, values of $\bar{d}$ for stream perlphyton have not been determined. The expected trend of perlphyton specles diversity in a stream recelving organic enrlchment in the headwaters would be low values upstream with an Increase downstream as water quality 1mproves.

Pigment diversity of phytoplankton communities has been related to nutrients and aging (Margalef, 1958)。 Plgment diversity is the ratio of the absorbance of $90 \%$ acetone extract at $430 \mathrm{~nm}$ and $665 \mathrm{~nm}_{\circ}$ Lowest values are usually found in young, growing populations and highest values in old, stable populations (Margalef, 1968). A stream having a longitudinal gradient of nutrients would be expected to exhibit a gradient of plgment diversity. However, Wilhm and Long (1969), working with laboratory microcosms were unable to establish a relationship of plgment diversity to nutrient levels or time。

Weber and McFarland (1969) have proposed an autotrophic index of periphyton to reflect the nature and severity of water pollution. The autotrophic index is defined as the ratio of ash-free welght to chlorophyll a concentration. Periphyton in unpolluted or slightly polluted waters are mostly algae and the autotrophic index 1s usually less than 100. Increased organic pollution may result in the algae being replaced by non-chlorophyllous organisms and an increase in the 
autotroph1c 1ndex. Th1s Index has not been widely evaluated with periphyton communities in enr1ched streams.

Productivity, specles diversity, and plgment diversity have been studied In many different types of communties, but few studies have attempted to investigate relationships among these parameters in perlphyton communities of streams. The objectives of the present study were to measure spatial and temporal varlation in productivity of the periphyton community in atream recelving domestic and oll refinery effluents, to relate species diversity and pigment diversity to levelo of productivity and degrees of pollution, and to evaluate the autotroph1c index as a method of characterfing water quality. 
CHAPTER II

\section{DESCRIPTION OF STUDY AREA}

\section{General Descr1pt1on}

Skeleton Creek originates near Enfd, Garfleld County, Oklahoma, flows southeasterly for $113 \mathrm{~km}$ through $\mathrm{KIngfisher}$ and Logan Countles and empties into the Clmarron R1ver $8 \mathrm{~km}$ north of Guthrie, Oklahoma (F1g. 1). Stream elevation 1 s $387 \mathrm{~m}$ at Enld and $227 \mathrm{~m}$ at the mouth. Average gradient is $0.9 \mathrm{~m} \mathrm{~km}^{-1}$. W1dth incredses to $15 \mathrm{~m}$ near the mouth with a mean annual flow of $1.4 \mathrm{~m}^{3} \mathrm{sec}^{-1}$ (W1Ihm and Dorrls, 1966). RIffles are abundant upstream and pools are more common in the downstream course. Depth in the riffles is often only a few $\mathrm{cm}$ while some pools are more than $1.5 \mathrm{~m}$. Low flow occurs throughout most of the year. The stream bottom is composed of rocks, grave1, sand, and s1lt. Based on the degree of branching (Horton, 1945) Skeleton Creek passes from a third order stream at the uppermost station to a sixth ordex stream at the lowermost station.

The Skeleton Creek dralnage basin lies in a mixed-grass pralrle assoclation. Topography is undulating pralries dissected by wooded valleys. The basin is approximately 106,230 ha (U.S。 Dept. of Interfor, 1968). Primary land uses are cultivation and pasture.

Exposed rocks in the drainage basin are sandstone and shales belonging to the Enid group of the Permian Red Bed (Gallowey, 1960). 


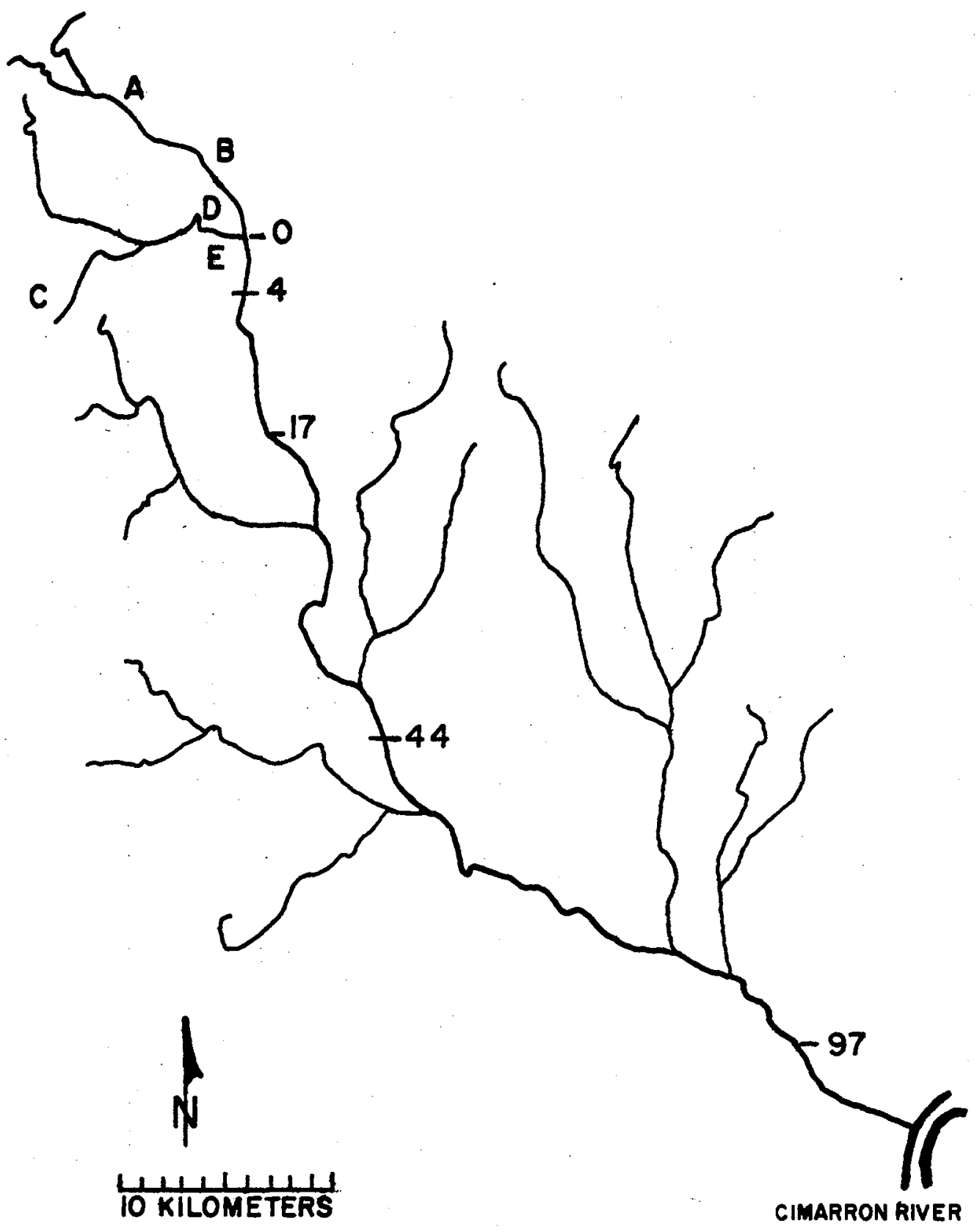

P1gure 1. Skeleton Creak with Sampling Stations Indicated by Distance in K1lometers Dewnotram from the Confluence with Boggy Creek. $A=$ Sewage Lagoons, $B=$ inlo S tate school utfall, C = Air Base Outfall, D = O1l Refinery Outfall, E = Enid Muntelpal Senrage Outfall 
Solls of the area belong to the Renfrow-Zane1s-Vernon association and are brown to reddish-brown clay or sandy loam (Gray and Galloway, 1959).

Climate of the area is continental with distinct seasonal variations in temperature. Summers are warm with temperatures often exceeding $40 \mathrm{C}$. Winters are mild with numerous short, cold periods. Temperature range for the 61-year period through 1955 was -31 C to $46 \mathrm{C}$ and averaged $15 \mathrm{C}$. Mean annual ralnfall was $76 \mathrm{~cm}$ for the 61-year perlod through 1958, minimum annual rainfall was $30.5 \mathrm{~cm}$ during 1936 and maximum was $132 \mathrm{~cm}$ for 1908 (Galloway, 1960).

\section{Source of Waste Effluents}

Five sources of municipal and Industrial wastes enter the headwaters of Skeleton Creek. Approximately $340 \mathrm{~m}^{3}$ day of domestic sewage effluent from two lagoons enter Skeleton Creek $10 \mathrm{~km}$ above $1 \mathrm{ts}$ confluence with Boggy Creek. Sewage effluent from Enid State School enters Skeleton Creek $3 \mathrm{~km}$ downstream from the sewage lagoons. Treatment faclifties at the school consist of an Imhoff Tank, a trickling filter, and a final settling basin. About $450 \mathrm{~m}^{3}$ of sewage is treated datly.

Effluents from three sources are discharged Into Boggy Creek, a small Intermittent stream. Domest1c wastes from an Alr Force Base enter Boggy Creek $16 \mathrm{~km}$ above 1ts confluence with Skeleton Creek. The waste treatment plant at the Afr Force Base has a primary settling basin, trickling filter, sludge-drying beds, and a final settling basin. Average outfall in May, 1964, was $700 \mathrm{~m}^{3} \mathrm{day}^{-1}$. The Enid municipal sewage effluent enters Boggy Creek about $1.5 \mathrm{~km}$ above the 
confluence with Skeleton Creek. Treatment Includes praaration, activated sludge, and sludge drylng. Approximately $15,000 \mathrm{~m}^{3} \mathrm{day}^{-1}$ of sewage are treated. About $70 \%$ of the flnal effluent from the sewage treatment plant is pumped to an oll refinery for use in the refinery process and the rest is discharged into Boggy Creek. Waste water from the o11 refinery is routed through an API trap for removal of 011 and Into a holding pond. The water is pumped Into a serles of six settling pits where it is mixed with boller blow-down and lime slurry. The waste water then passes through five biological oxidation ponds, enters a small ditch and flows into Boggy Creek $90 \mathrm{~m}$ above the Enid sewage treatment outfall. Final effluent is $750 \mathrm{~m}^{3}$ day ${ }^{-1}$.

$$
\text { Sampling Stations }
$$

Four stations were selected for study and were numbered according to their distance in $\mathrm{km}$ downstream from the confluence of Boggy and Skeleton Creek (FIg. 1). An attempt was made to select stations with similar physical properties so any observed differences might be attributed to the effect of organic enrichment. 


\section{CHAPTER III}

METHODS

Sampling Times

Th1s study was based on collections made from October, 1967 through October, 1968. Five exposure periods of approximately two months each were used. The exposure perlods were divided into flve seasons. Fall included the period from October 26 to December 28 , 1967. Winter was from January 23 to March 23, 1968. Spring extended from March 23 to June 27, 1968. Summer was from July 5 to August 12, 1968. The late summer period was from September 7 to October 22, 1968. Cofflections were made at 3 to 7 day intervals during each exposure period.

\section{Phys1 cochemical}

Measurements of temperature, $\mathrm{pH}$, conductivity, 11ght transmission, alkalinfty, dissolved oxygen, and current were made at each station during each sampling time. Water temperature was determined with a mercury centigrade thermometer. Hydrogen-ion concentration, expressed as $\mathrm{pH}$, was measured with a Hellige Comparator. Conduct1vity was determined with an Industrial Instruments Conductivity Bridge. LIght transmission was measured with a Bausch and Lomb Spectronic 20 colorimeter. Phenolphthalein and methyl purple alkalinity were measured by titration with $0.02 \mathrm{~N}$ sulfurlc acld. Dupllcate dissolved 
oxygen samples were flxed by the Alotarbarg (An1de) Modification of the W1nkler Method (A, P. H, A., 1960). Current was estimated following the method of RobIns and Crawford (1954).

\section{B1olog1cal}

plexigles plates mounted vertically on a raft were used at each station to sample periphyton. Rafte were a $50 \times 125$ cm rectangle of $2.5 \times 5 \mathrm{~cm}$ redwood slats with an additional slat inserted in the middle of the long axis. A pointed extension of $6 \mathrm{~mm}$ hardware cloth was added to the front to divert debris. Twelve Plexiglas plates, each $5 \times 12 \mathrm{~cm}$, were attached with bolts and wing nuts to each of the three slats on the long axis. A pilot study was conducted during September, 1967, to test the durabllity of the raft and to provide information on exposure times.

Three plates were removed from each raft on each sampling day. During the latter part of the study an additional plate was removed on alternate dates for pigment analysis. Each side of a plate was consldered a sample and was specifled by drawing numbered cards.

Blomass as ash-free welght was determined from three samples at each station for each sampling date. Perlphyton was scraped with a glass microscope slide into a cruclble. Ash-free welght was determined by drying the material in an oven at $105 \mathrm{C}$ for 24 hours and ashing in a muffle furnace at $550 \mathrm{C}$ for 1 hour.

The data were graphed to determine the colonization, acceleration, and asymptotic phase of growth. Three linear components were suggested 
In the growth curves and the following discontinuou linear ragranion model was developed to analyze the data:

$$
Y=d\left(b_{1} t\right)+e\left[a+b_{2}\left(t-t_{1}\right)\right]+f\left[c+b_{3}\left(t-t_{f}\right)\right]
$$

where $Y$ is the standing crop, $b_{1}$ is the slope of the colonization phase, $b_{2}$ is the slope of the acceleration phase, $b_{3}$ is the slope of the asymptotic phase, $t$ is time, $t_{1}$ is the time at the intersection of $b_{1}$ and $b_{2}, t_{f}$ is the time at the intersection of $b_{2}$ and $b_{3}, d, e$, and $f$ are coefficlents determined such that if

$$
\begin{aligned}
& t<t_{1}, d=1, e=0, f=0 \\
& t_{1}<t<t_{j}, e=1, d=0, f=0 \\
& t>t_{j}, f=1, e=0, d=0
\end{aligned}
$$

a Is the value of $Y$ at time $t_{i}$, $G$ is the value of $Y$ at time $t_{j}$ 。 Regression lines were determined by the least squares method。 Differences in $b_{2}$ slopes were compared using an analysis of variance and a mult1ple t-test (Steele and Torrie, 1960)。A t-test was conducted to determine if $b_{3}$ slopes differed significantly from zero.

Samples to be used for determining specles diversity were scraped from the plates and preserved in $3 \%$ formalin. Two subsamples from each of two samples were used for counting the number of individuals in each spectes. Third samples were held in reserve.

The number of Individuals necessary to obtain a species diversity value independent of sample size was evaluated by graphic and statistical methods from collections wade during the fall and spring. One thousand Individuals in units of 100 were counted from each of the four subsamples 
for each station. A diverelty Index wes calculated for aach progressively increasing sample alze of 100. Values of diversity from sample s1ze 100 to 1,000 were plotted to determine if $\bar{d}$ reached an asymptote. No analysis of varlance could be performed with this mathod sinfe samples were not independent.

Independent samples were obtained by dividing the 1,000 ind1viduals Into groups of size $100,200,300$, and 400。 Estimates of $\bar{d}$ were calculated for each sample slze and an analysis of variance was performed to test for slgniflcant differences among $\bar{d}$ values obtalned from the Independent samples.

Perlphyton for plgment analysls was scraped from plates Into test tubes containing $90 \%$ acetone. Plgments were extracted in the dark at $4 \mathrm{C}$ for $24 \mathrm{hr}$ 。 Samples were then centrifuged for $5 \mathrm{~min}$, the supernatant was transferred to a $1 \mathrm{~cm}$ cuvette, and the sample was scanned from $430 \mathrm{~nm}$ to $750 \mathrm{~nm}$ in a Perkin-EImer spectrophotometer。 P1gment concentrations were calculated according to the equations of Parsons and Strlckland (1963). Readings ware taken rellat1ve to the chlorophyll a peak even if displaced laterally (Banse and Anderson, 1967)。 
CHAPTER IV

RESULTS AND DISCUSSION

Phy al cochamical

Mean sumer water temperature at the four tation ranged from $27.1 \mathrm{C}$ to $29.6 \mathrm{C}$ (Tab1e I). Maximum tomperature recorded was $33 \mathrm{C}$ at Station 4 on July 14, 1968. Spring and late sumer temperatures were similar as were fall and winter. Ice covered all stations during late December。 Highest temperatures occurred at Station 4 probably due to the shallow, unshaded condition of the stream at this station. The stream banks were shaded downstream and pools were deepor.

The mean seasonal pH ranged from 7.6 to 8.3 (Table I)。 The pH at Station 4 and 97 was generally higher than at Station 17 and 44, but differences were small. Little seasonal variation was evident among the four stations.

Daytime dissolved oxygen concentration ranged from 2.2 ppm to 17.2 ppm (Table I)。Hfghest values were measured at Station 4 for all seasons. During the winter and spring dissolved oxygen values generally decreased downstream. During fall, summer, and late summer highest values occurred at Station 4 followed by Station 97. Lowest values occurred at Station 17. Low oxygen concentration during late sumer possibly resulted from heavy runoff carrying oxygen-demanding wastes further downstream。 
TABLE I

MEAN SEASONAL PHYSICOCHEMICAL CONDITIONS

\begin{tabular}{|c|c|c|c|c|c|c|c|}
\hline Season & Station & $\begin{array}{c}\text { Temperature } \\
\text { (C) }\end{array}$ & $\mathrm{pH}$ & $\begin{array}{l}\text { Dissolved } \\
\text { Oxygen } \\
\text { (ppm) }\end{array}$ & $\begin{array}{c}\text { Alkalinity } \\
(\mathrm{ppm})\end{array}$ & $\begin{array}{l}\text { Light } \\
\text { Trans. } \\
\text { (\%) }\end{array}$ & $\begin{array}{c}\text { Conductivity } \\
\text { ( } \mu \text { mhos })\end{array}$ \\
\hline Fall & $\begin{array}{r}4 \\
17 \\
44 \\
97\end{array}$ & $\begin{array}{l}8.6 \\
7.2 \\
7.0 \\
7.2\end{array}$ & $\begin{array}{l}8.1 \\
7.8 \\
7.6 \\
8.0\end{array}$ & $\begin{array}{r}10.7 \\
6.5 \\
6.6 \\
10.2\end{array}$ & $\begin{array}{l}308 \\
300 \\
267 \\
234\end{array}$ & $\begin{array}{l}76 \\
84 \\
52 \\
56\end{array}$ & $\begin{array}{l}1557 \\
1730 \\
1427 \\
1289\end{array}$ \\
\hline Winter & $\begin{array}{r}4 \\
17 \\
44 \\
97\end{array}$ & $\begin{array}{r}11.0 \\
8.0 \\
10.3 \\
7.7\end{array}$ & $\begin{array}{l}8.2 \\
8.1 \\
8.0 \\
8.1\end{array}$ & $\begin{array}{r}14.9 \\
12.5 \\
9.2 \\
11.5\end{array}$ & $\begin{array}{l}289 \\
272 \\
264 \\
236\end{array}$ & $\begin{array}{l}66 \\
73 \\
81 \\
89\end{array}$ & $\begin{array}{l}1793 \\
2054 \\
1893 \\
1763\end{array}$ \\
\hline Spring & $\begin{array}{r}4 \\
17 \\
44 \\
97\end{array}$ & $\begin{array}{l}20.8 \\
19.3 \\
18.0 \\
17.3\end{array}$ & $\begin{array}{l}8.2 \\
8.3 \\
8.0 \\
8.0\end{array}$ & $\begin{array}{r}17.2 \\
11.4 \\
10.8 \\
8.2\end{array}$ & $\begin{array}{l}306 \\
330 \\
281 \\
314\end{array}$ & $\begin{array}{l}65 \\
54 \\
62 \\
33\end{array}$ & $\begin{array}{l}1916 \\
2129 \\
1608 \\
1085\end{array}$ \\
\hline Summer & $\begin{array}{r}4 \\
17 \\
44 \\
97\end{array}$ & $\begin{array}{l}29.6 \\
27.1 \\
27.5 \\
28.8\end{array}$ & $\begin{array}{l}8.3 \\
8.0 \\
8.1 \\
8.3\end{array}$ & $\begin{array}{r}10.7 \\
6.1 \\
8.6 \\
8.4\end{array}$ & $\begin{array}{l}285 \\
202 \\
213 \\
234\end{array}$ & $\begin{array}{l}60 \\
57 \\
53 \\
58\end{array}$ & $\begin{array}{l}1904 \\
1896 \\
1585 \\
1301\end{array}$ \\
\hline Late Summer & $\begin{array}{r}4 \\
17 \\
44 \\
97\end{array}$ & $\begin{array}{l}22.4 \\
19.7 \\
20.8 \\
21.2\end{array}$ & $\begin{array}{l}8.2 \\
7.7 \\
7.8 \\
8.1\end{array}$ & $\begin{array}{r}12.8 \\
2.2 \\
5.2 \\
9.4\end{array}$ & $\begin{array}{l}315 \\
306 \\
268 \\
238\end{array}$ & $\begin{array}{l}64 \\
66 \\
37 \\
28\end{array}$ & $\begin{array}{r}1828 \\
2097 \\
1512 \\
1091\end{array}$ \\
\hline
\end{tabular}


Alkalinity varled Jetween $202 \mathrm{ppm}$ and $315 \mathrm{ppm}$ (Table I)。Alkalinity was primarily due to bicarbonate since phenophthalein alkalinity was detected on only two occaslons. In general, alkalinity decreased downstream (Table I)。 The higher levels upstream possibly resulted from the lime slurry method of treating waste water at the ofl refinery to remove emulsifled ofl particles. Reduction downstream was due to precipitation and dilution. The seasonal trend wa highest values during the spring followed by late sumer, fall, winter, and sumer. Interference in the colorimetric method for detarmining alkalinity occurred during perlodo of low light transmission. Filtering the ample before adding methyl purple helped remove the interforence.

In general, light transmision decreased downstream except in winter (Table I). Values varled from a minimum of $33 \%$ to $84 \%$. Decreased 11 ght transmission downstream was due to erosion of adjacent cultivated land, Inflow from tributarles, and resuspension of silt from the streambed (Baumgardner, 1966). High light transmission occurred during the winter. Rainfall totaled only $4.1 \mathrm{~cm}$ during this perfod and stream flow was low allowing for settling of suspended particles.

Conductivity ranged from 1085 u mhos to 2129 u mhos (Table I). The general pattern was for the highest values to occur at the two upstream stations. Lowest values occurred at Station 97. The decrease in conductivity downstream was due to dilution and Incorporation of lons by algae (Hynes, 1966).

Precipitation was highest during the spring and summer (F1g, 2). The stream overflowed the banks several t1mes during these two seasons. The lowest amount of preclpitation occurred during the winter followed by late summer and fall. 


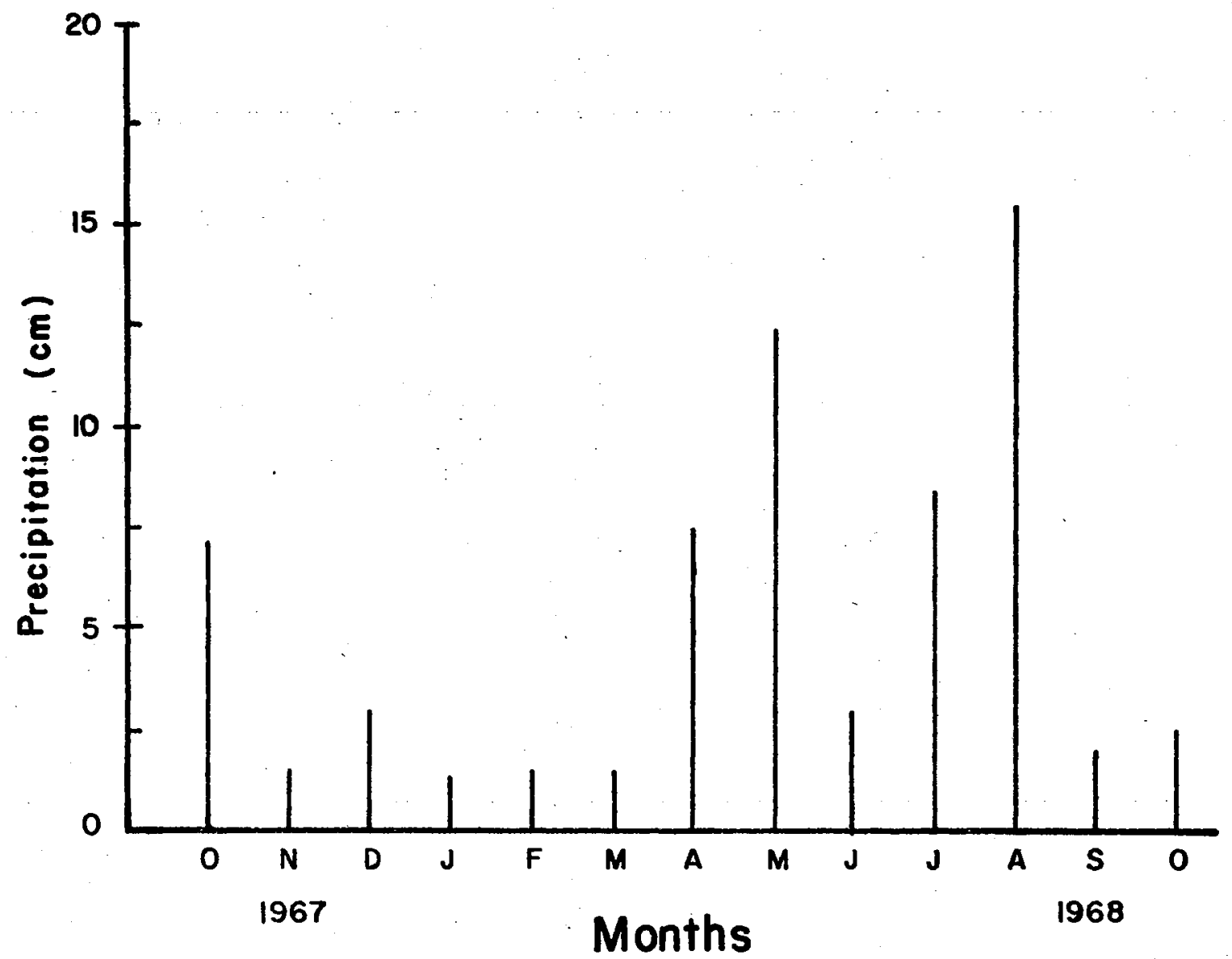

Figure 2. Precipitation Amounts Recorded at EnId, Oklahoma, by the U. S. Veather Bureau 
Commun1ty Composition

Dlatoms dominated the algal flore of Skeleton Creek。 Fourteen of the 22 observed taxa belong to the Baclllarfophyceae (Table II)。 Euglena vlr1dis was the only other alga to occur In large numbers during the study. The two upetream stations were completely dominated by Euglena VIr1dis during the winter.

Photomfcrographe of the alga collected during the tudy are deposited In the herbar1um of Oklahoma State Univera1ty.

\section{BLomass Accumulation}

The use of a discontinuous linear regression model permitted separating a growth curve into a colonization, acceleration, and asymptotic phase. Slope $b_{1}$ represents the initial colonization phase and was considerably lower then the acceleration phase, slope $b_{2}$ (Table III). The time required for colonization during the fall at all stations and during the summer for Station 44 and 97 ranged from 10 to 18 days. Colonization time was less than 10 days for other stations and seasons. Colonization slopes were not computed if the acceleration phase started before the second sampling time。

The rate of colonization is influenced by the kinds of organisms present, substrata, and the number of avallable propagules. Dlatoms were the major component of the periphyton community in Skeleton Creek. Glass slides collected representative samples of species of diatoms in a river (Patrick et al., 1954). No slgniflcant difference was found in relative abundance of ep1lithic and eplphytic diatom species and most other ephermal epilithic algae on smooth glass, frosted glass, smooth plexiglas, and frosted Plexiglas (Castenholz, 1961). Propagules for the colonization 
TABIE II

ALGAE IDENTIFIED DURING THE STUDY

Chlorophyta

Cosmarium ep.

Pediastrum duplex

Scanedesmun quadrangulata

st18eoclonium tenue

Euglenophyta

Euglene viridis

Phacus sp.

Chrysophyta

Amph1prora paludosa

Cocconeis sp.

Cyclotella meneghiniank

Cymbella affinis

Cymbella sp.

Fragliaria erotonens1.8

Frustulina vulgarls

Gomphonema ol1vacium

Nitzschia acicularis

Nitzschia hungarica

Nitzschia palea

Pleuros Igme delicatulum

Surle1la angustata

Surlella ovata

Synedra ulna

Cyanophyta

Osc11lator1a sp. 
TABLE III

SLOPES FOR THE THREE GROWTH PHASES AT STATIONS IN SKELETON CREEK FOR THE FIVE SAMPLING PERIODS

\begin{tabular}{|c|c|c|c|c|}
\hline Slope & Station 4 & Station 17 & Station 44 & Station 97 \\
\hline & & \multicolumn{2}{|c|}{ Fal1 } & . \\
\hline $\mathrm{b}_{1}$ & 0.05 & 0.17 & 0.01 & 0.04 \\
\hline$b_{2}$ & 1.98 & 1.28 & 0.80 & 0.67 \\
\hline$b_{3}$ & -0.23 & 0.04 & -0.19 & 0.21 \\
\hline & & \multicolumn{2}{|c|}{ Winter } & \\
\hline$b_{1}$ & - & - & - & - \\
\hline$b_{2}$ & 2.70 & 1.38 & 0.87 & 0.54 \\
\hline$b_{3}$ & 0.60 & -0.96 & $-1.48 *$ & - \\
\hline \multicolumn{5}{|c|}{ Spring } \\
\hline $\mathrm{b}_{1}$ & - & - & - & - \\
\hline$b_{2}$ & 2.28 & 3.73 & 2.16 & 0.53 \\
\hline$b_{3}$ & - & - & - & - \\
\hline \multicolumn{5}{|c|}{ Summer } \\
\hline $\mathrm{b}_{1}$ & - & - & 0.30 & 0.08 \\
\hline$b_{2}$ & 0.96 & 1.61 & 0.80 & 0.64 \\
\hline$b_{3}$ & - & -0.52 & -0.40 & -0.25 \\
\hline \multicolumn{5}{|c|}{ Late Summer } \\
\hline$b_{1}$ & - & - & - & - \\
\hline$b_{2}$ & 0.86 & 0.75 & 0.62 & 1.17 \\
\hline$b_{3}$ & -0.12 & -0.03 & -0.07 & $-0.24 *$ \\
\hline
\end{tabular}

- Indicates insufficient data to calculate a slope value. *b, slopes significantly different from zero. 
of new substrata in Skeleton Creek are provided by detached periphyton mats. The upstream stations had a h1gher colonization rate except when a large amount of detergent foam was present. It is possible that detergents Interfere with the adhesion of organisms to a substrate, thus reducing the colonization rate.

The slope of the regression 11ne fitted to the acceleration phase of growth, $b_{2}$, was used to estimate periphyton productivity for each station and season (Table III)。 Slope values correspond to periphyton productivity In $\mathrm{g} \mathrm{m}^{-2} \mathrm{day}^{-1}$. Analysis of varfance coupled with a multiple t-test was used to test for diffarences among stations for ach season (Tablo IV). Product1vity as measured by the slope of the acceleration phase of growth, $b_{2}$, exhlbited distinct longltudinal variation in Skeleton Creek. Longltudinal varlation in productivity was similar for the fall and winter (F1gs, 3 and 4)。 Greatest product1vity occurred at Station 4 and decreased progressively downstream。 The multiple t-test Indicated that the two upstream stations were signiffcantly greater in rate of accumulation than the two downstream stations (Table IV).

Productivity at the three upstream stations during spring was higher than at Station 97 (Table IV and $\mathrm{Flg}_{\alpha}$ 5)。 Station 17 had the maximum productivity recorded during the ent1re study, $3.73 \mathrm{~g} \mathrm{~m}^{-2} \mathrm{day}^{-1}$, and was statistically greater than the other three stations. The minimum value of productivity, $0.053 \mathrm{~g} \mathrm{~m}^{-2}$ day ${ }^{-1}$, was also recorded during the spring at Station 97. Station 4 and 44 were not significantly different from each other.

During summer, productivity at Station 17 was signficiantly greater than the other three stations (Table IV and FIg, 6). Station 4, 44, and 97 were not significantly different from each other。 
TABLE IV

\section{COMPARISON OF $b_{2}$ SLOPES WITH STATIONS RANKED FROM LOWEST TO HIGHEST PRODUCTIVITY VALUES*}

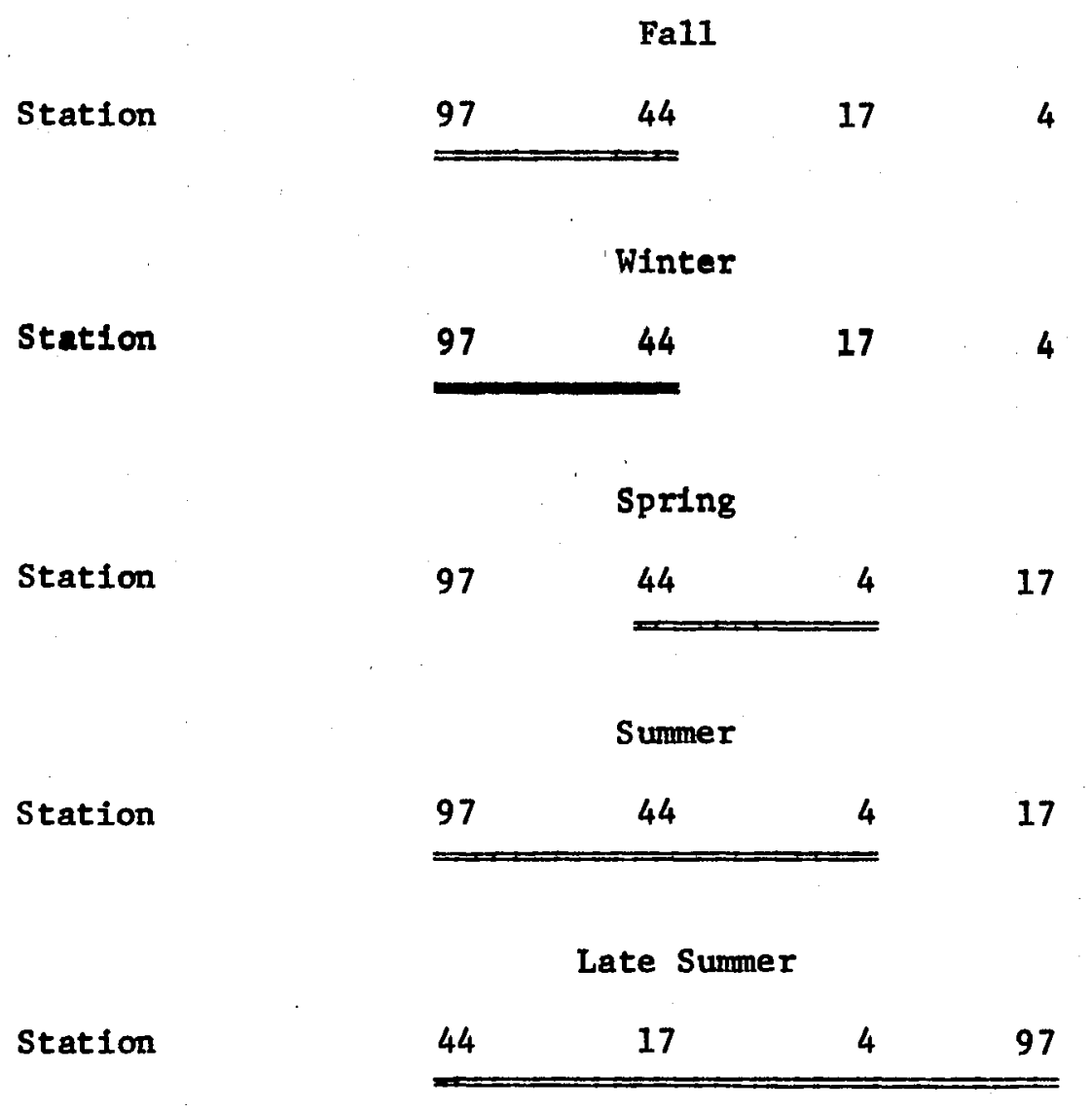

*Stations underscored by the same line are not judged to be significantly different $(\alpha=0.05)$. 


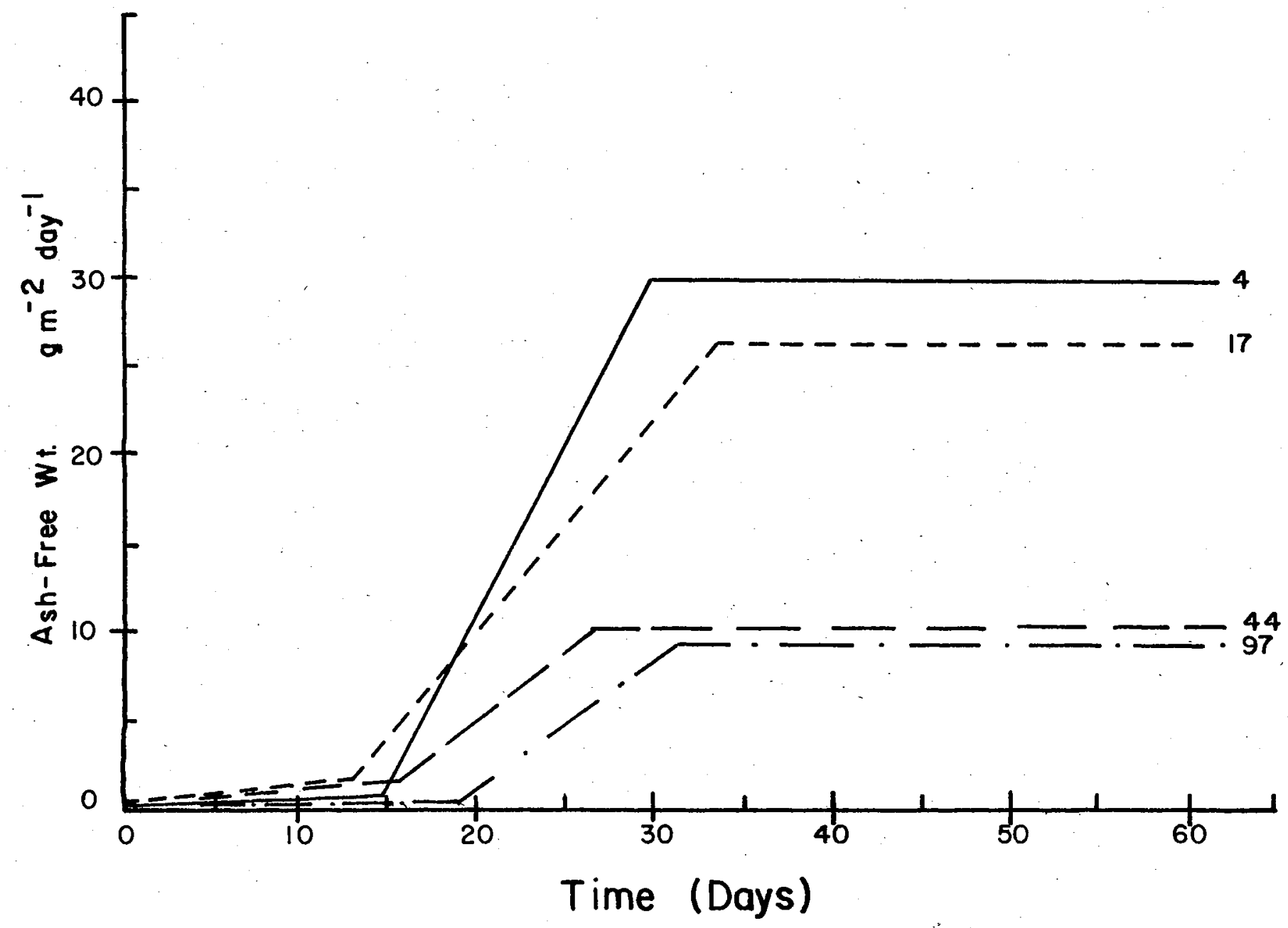

Figure 3. Discontinuous Linear Regression Model Fitted to Growth of Periphyton for the Fall 


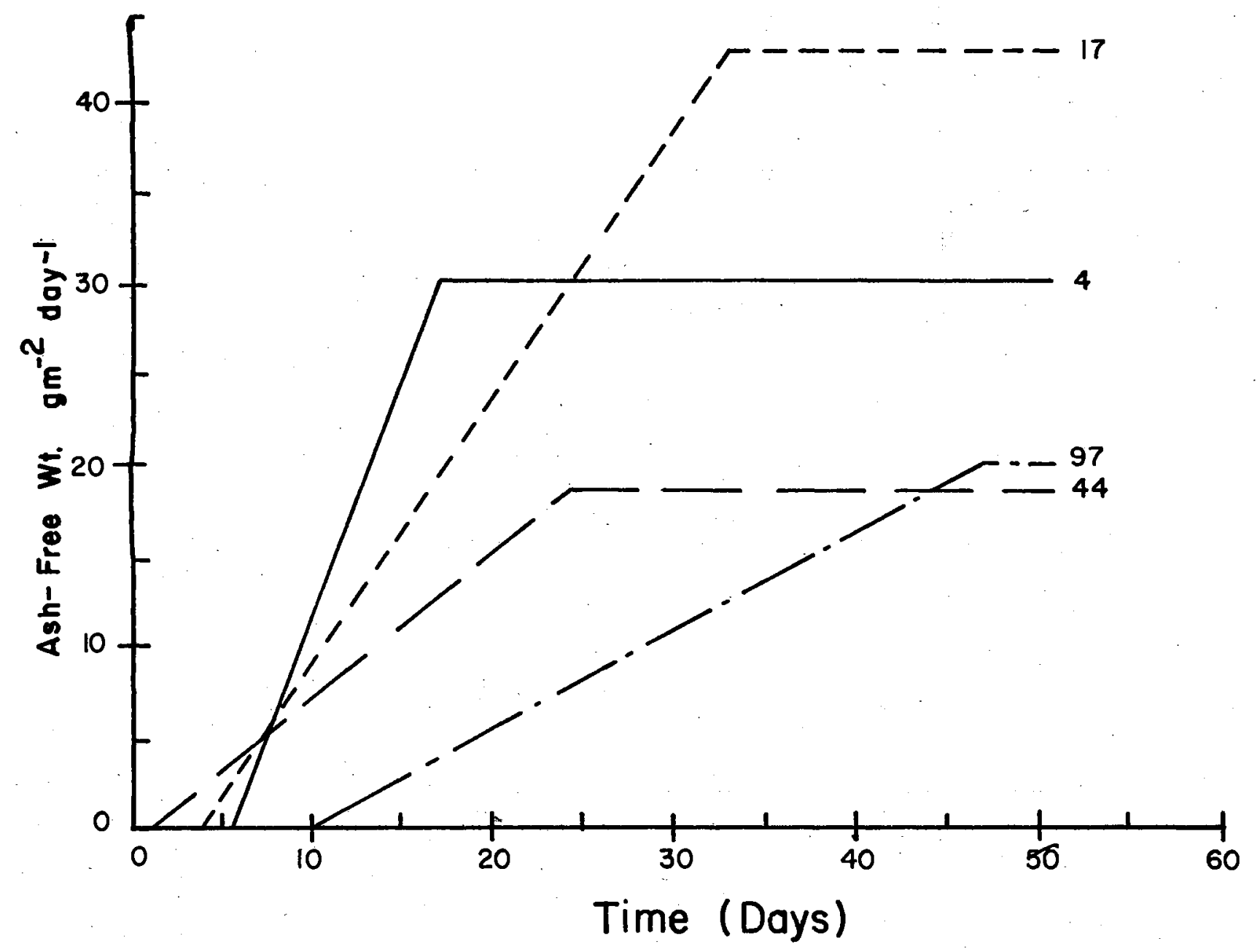

Figure 4. Discontinuous Linear Regression Model Fitted to Growth of Periphyton for the Winter 


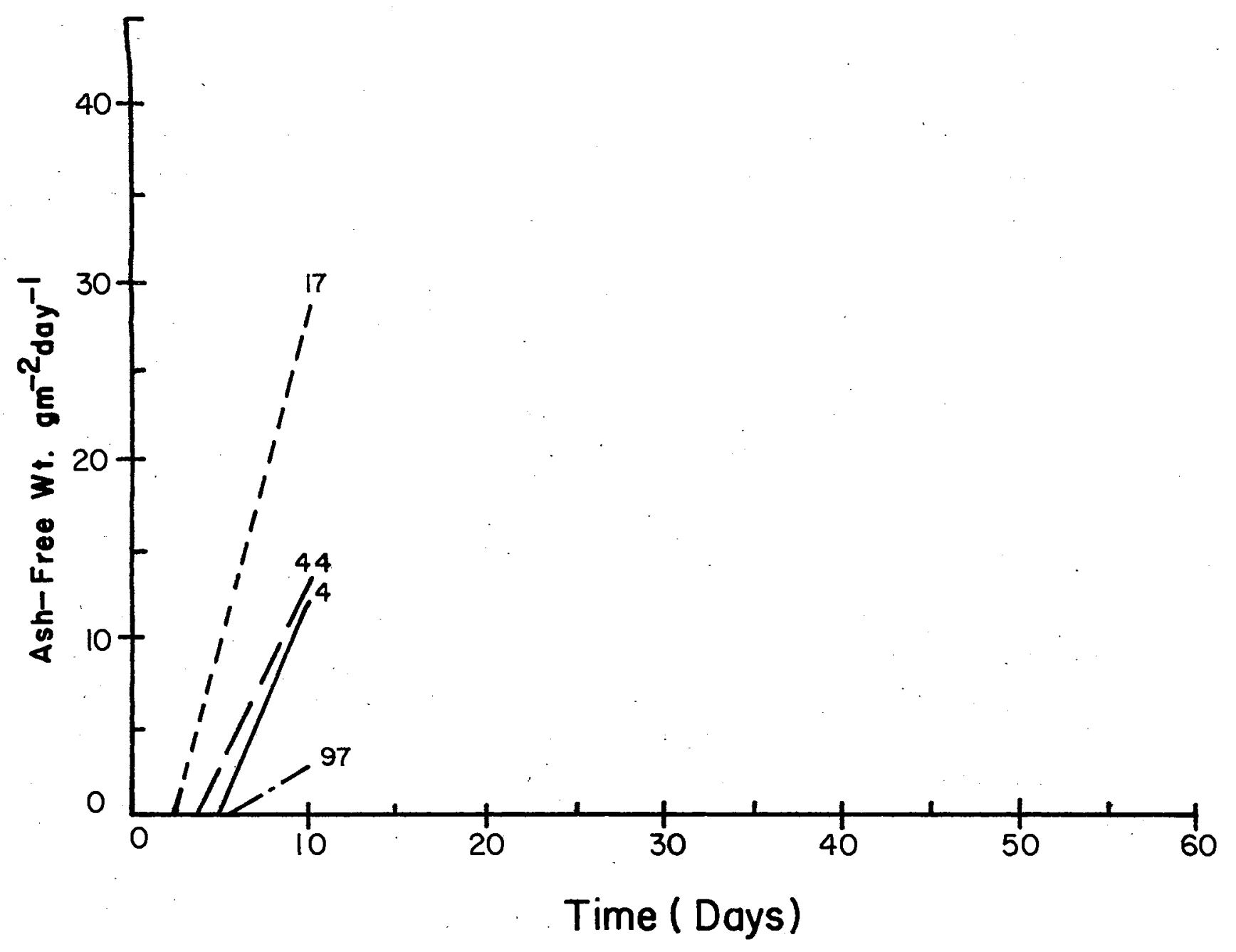

Figure 5. Discontinuous Linear Regression Model Fitted to Growth of Periphyton for the Spring 


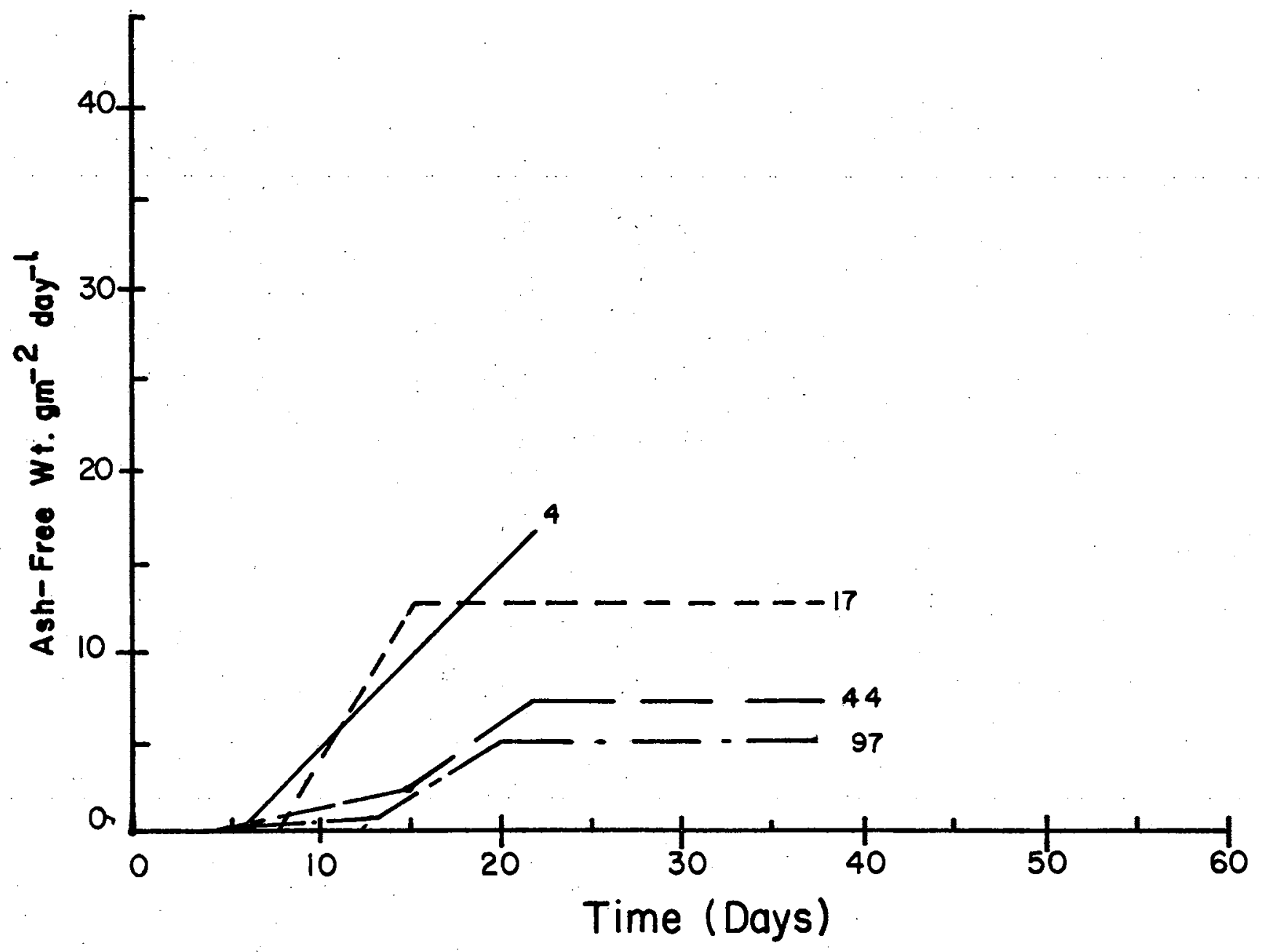

Figure 6. Discontinuous Linear Regression Model Fitted tn Grovth of Periphyton for the Summer 
Although no significant difference in rate of accumulation among stations for late summer was found ( $\mathrm{Tabla} I V$ and $\mathrm{FIg}, 7$ ), productivity was h1ghest at Station 97. Dense phytoplankton blooms were observed in the downstream pools during this period and possibly contributed to productivity at Station 97.

Considerable seasonal variation in productivity was measured during the study (Table III). Values were generally higher in spring followed by winter, fall and summer. Lowast seasonel productivity occurred during the late sumer. The high productivity recorded during the ophing wes due to the spring maxima of algal growth and abundance of avallabla nutrlents (Blum, 1956).

Nutrlents such as nitrates, phosphates, and potassium which stimulate plant growth are products of the breakdown of organlc matter, particularly sewage. Below zones of heavy organic pollution the amounts of these substances are often greatly in excess of their normal concentrations in natural waters (Hynes, 1966). Four sources of domestic sewage and an o11 refinery effluent enter Skeleton Creek above Station 4 . The effluent undoubtedily carries a large amount of nutrlents. A progressive decrease In productivity downstream from the effluent outfalls is attributed to uptake of nutrients by large numbers of periphyton upstream, dilution by Inflow from tributarles, and lower light transmission (Baumgardner, 1965).

Estimates of primary productivity from varlous studies and the mean annual values from Skeleton Creek are glven in Table V. All values were determined by blomass accumulation. Productivity at the two upstream stations In Skeleton Creek greatly exceeds the estlmates from other studies. Station 44 has a considerably lower value than the upstream 


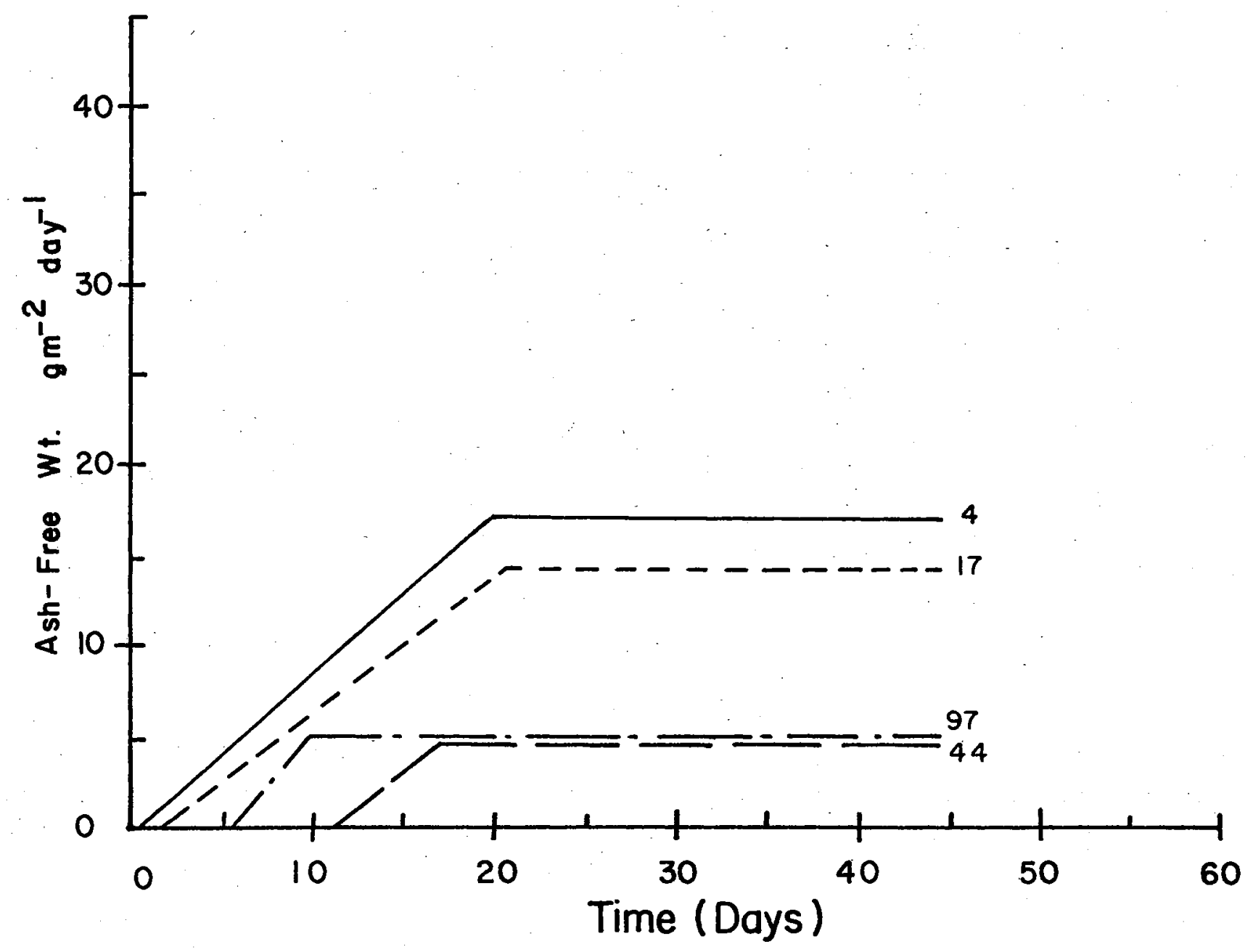

Figure 7. Discontinuous Linear Regression Model Fitted to Growth of Periphyton for the Late Summer 
TABLE V

COMPARISON OF PERIPHYTON PRODUCTIVITY ESTIMATES FROM VARIOUS HABITATS

\begin{tabular}{|c|c|c|c|}
\hline Habitat & Treatment & $\begin{array}{l}\text { Productivity } \\
\left(\mathrm{g} \mathrm{m}^{-2} \text { day }^{-1}\right)\end{array}$ & Reference \\
\hline Skeleton Creek & $\begin{array}{c}4 \mathrm{~km} \text { below } \\
\text { outfalls }\end{array}$ & 1.75 & Present Study \\
\hline Skeleton Creek & $\begin{array}{l}17 \mathrm{~km} \text { below } \\
\text { outfalls }\end{array}$ & 1.75 & Present Study \\
\hline Skeleton Creek & $\begin{array}{l}44 \mathrm{~km} \text { below } \\
\text { outfalls }\end{array}$ & 1.05 & Present Study \\
\hline Microcosm & $\begin{array}{l}\text { High levels of } \\
N \text { and } P\end{array}$ & 0.75 & Wilhm and Long (1969) \\
\hline Skeleton Creek & $\begin{array}{l}97 \mathrm{~km} \text { below } \\
\text { outfalls }\end{array}$ & 0.71 & Present Study \\
\hline Red Cedar River & $\begin{array}{l}\text { Warm-water } \\
\text { stream }\end{array}$ & 0.58 & Grezenda et al. (1968) \\
\hline Artificlal Stream & Grazing & 0.58 & Kehde (1969) \\
\hline Artificlal Stream & No grazing & 0.51 & Kehde (1969) \\
\hline Artificial Stream & None & 0.51 & Kevern et al. (1966) \\
\hline Microcosm & $\begin{array}{l}\text { Intermediate } \\
\text { levels of } \\
N \text { and } P\end{array}$ & 0.40 & Wilhm and Long (1969) \\
\hline Ponds & Fertilizer & $0.30-0.44$ & Knight and Ball (1962) \\
\hline Spring & & 0.20 & Kevern et al. (1966) \\
\hline Mi crocosm & $\begin{array}{l}\text { Low levels of } \\
N \text { and } P\end{array}$ & 0.14 & Wilhm and Long (1969) \\
\hline
\end{tabular}


stations but is still higher than the other studies. Productivity at Station 97, fartherest downstream from the outfalls, is comparable to microcosms with high levels of nitrogen and phosphorus, artificial streams, and a warm water stream。 The value for Station 97 exceeds that of microcosms with intermediate and low levels of nitrogen and phosphorus, ponds treated with fertilizer, and a spring.

Slope $b_{3}$, the asymptotic level was not significantly different from zero $(\alpha=0.05)$ in 12 of 14 measured intervals (Table III). Zero slope is maintained when increases in blomass are balanced by sloughing and grazing.

Mean seasonal blomass maintained at the asymptotic level ranged from $4.5 \mathrm{~g} \mathrm{~m}^{-2}$ to $40.7 \mathrm{~g} \mathrm{~m}^{-2}$ (FIgs. 3 to 7). Blomass was simflar for the two upstram stations with lower values measured at the two downstream stations. Stations with the highest productivity generally had the largest biomass. Estimates of both productivity and blomass are necesisy to distinquish between a large blomass metabolizing at a slow rate and a small blomass metabolizing at a high rate.

Rat1o of Net Productivity to Blomass

Margalef (1958) found that as succession proceeded in phytoplankton communities in the rla of V1go the ratlo of net product1vity to blomass decreased, He recognized three stages of succession. Stage one was characterized by small-celled organisms with a $P_{n} / B$ ratio of 0.5 to 2.0 . This type of community developed in turbulent waters with a high nutrient concentration. Stage two was composed of medium-sized diatoms and had a $P_{n} / B$ ratio of 0.2 to 0.5 . Stage three was large free-swimming forms with a $P_{n} / B$ of less than 0.2 . 
In the present study no definite trend in spatial or tamporal variation in the $P_{n} / B$ ratio was observad (Table VI). Values ranged from 0.03 to 2.40 . Only one value was in the range of stage two and all others were in stage three. All values would have been much less had dry-welght Instead of ash-free welght been used for biomass. W1 Ihm and Long (1969) used dry welght and found the range of values proposed by Margalef not to be applicable to thelr study of microcosms. All their values were characterlatic of the third stage of succession.

Sample S1ze

W11hm and Dorr1. (1968) have hown that as semple size of benthic mecrolnvartebrates 10 Incraased, values of species divars1ty, $\bar{d}$, Increases rapidly at f1rst and then reaches an asymtote. Kochsiek (1970) found $\bar{d}$ of zooplankton to reach an asymptote as sample size was increased. The number of Individuals in the present study necessafy to obtain a $\bar{d}$ value independent of sample size was determined from collectlons made during the fall and spring. One thous and individuals In units of 100 were counted from each of four subsamples for each station. A diversity value was calculated for each progressively Increasing sample size of 100. Mean values of diversity from 100 to 1,000 were plotted to determine if $\overline{\mathrm{d}}$ reached an asymptote (Table VII). Graphical evaluation did not Indicate a difference in $\bar{d}$ among sample size of 100 to 1,000 . No analysis of varlance could be performed with this methed as the pooled samples were not independent.

Independent samples for statistical analysis were obtained by dividing the 1,000 Individuals into groups of size $100,200,300$, and 400. Values of $\bar{d}$ were calculated for each of the groups (Table VIII). 
TABLE VI

RATIO OF NET PRODUCTIVITY TO BIOMASS IN SKELETON CREEK

\begin{tabular}{lcccc}
\hline \multirow{2}{*}{ Season } & \multicolumn{4}{c}{ Station } \\
\cline { 2 - 5 } Fal1 & 4 & 17 & 44 & 97 \\
Winter & 0.06 & 0.17 & 0.08 & 0.07 \\
Spring & 0.10 & 0.03 & 0.05 & 0.03 \\
Summer & - & - & - & - \\
Late Summer & - & 0.12 & 0.11 & 0.11 \\
& 0.05 & 0.05 & 0.10 & 0.24 \\
\hline
\end{tabular}

- indicates insufficient data to calculate a $\mathrm{P}_{\mathrm{n}} / \mathrm{B}$ ratio. 
TABLE VII

MEAN DIVERSITY VALUES OBTAINED BY POOLING SUCCESSIVE SAMPLES FOR THE FALL AND SPRING

\begin{tabular}{|c|c|c|c|c|c|c|c|c|c|c|c|}
\hline \multirow{2}{*}{ Seas on } & \multirow{2}{*}{ Station } & \multicolumn{10}{|c|}{ Sample Size } \\
\hline & & 100 & 200 & 300 & 400 & 500 & 600 & 700 & 800 & 900 & 1,000 \\
\hline \multirow[t]{4}{*}{ Fall } & 4 & 1.6 & 1.6 & 1.6 & 1.6 & 1.6 & 1.6 & 1.6 & 1.6 & 1.6 & 1.6 \\
\hline & 17 & 1.1 & 1.1 & 1.2 & 1.2 & 1.2 & 1.2 & 1.2 & 1.2 & 1.2 & 1.2 \\
\hline & 44 & 1.2 & 1.3 & 1.3 & 1.3 & 1.3 & 1.3 & 1.4 & 1.4 & 1.4 & 1.4 \\
\hline & 97 & 2.2 & 2.2 & 2.2 & 2.2 & 2.2 & 2.2 & 2.2 & 2.2 & 2.2 & 2.2 \\
\hline \multirow[t]{4}{*}{ Spring } & 4 & 0.3 & 0.3 & 0.3 & 0.3 & 0.3 & 0.3 & 0.3 & 0.3 & 0.3 & 0.3 \\
\hline & 17 & 0.9 & 1.0 & 1.0 & 1.0 & 1.0 & 1.0 & 1.0 & 1.0 & 1.0 & 1.0 \\
\hline & 44 & 1.3 & 1.4 & 1.3 & 1.3 & 1.3 & 1.3 & 1.3 & 1.3 & 1.3 & 1.3 \\
\hline & 97 & 1.8 & 1.9 & 1.9 & 1.9 & 1.9 & 1.9 & 1.9 & 1.9 & 1.9 & 1.9 \\
\hline
\end{tabular}


TABLE VIII

MEAN DIVERSITY VALUES OBTAINED FROM INDEPENDENT SAMPLES FOR THE FALL AND SPRING

\begin{tabular}{|c|c|c|c|c|c|}
\hline \multirow{2}{*}{ Season } & \multirow{2}{*}{ Station } & \multicolumn{4}{|c|}{ Sample Size } \\
\hline & & $\overline{100}$ & 200 & 300 & 400 \\
\hline \multirow[t]{4}{*}{ Fall } & 4 & 1.6 & 1.6 & 1.6 & 1.5 \\
\hline & 17 & 1.1 & 1.2 & 1.2 & 1.0 \\
\hline & 44 & 1.2 & 1.3 & 1.3 & 1.4 \\
\hline & 97 & 2.2 & 2.2 & 2.2 & 2.2 \\
\hline \multirow[t]{4}{*}{ Spring } & 4 & 0.3 & 0.3 & 0.3 & 0.3 \\
\hline & 17 & 0.9 & 0.9 & 1.1 & 1.0 \\
\hline & 44 & 1.3 & 1.3 & 1.3 & 1.3 \\
\hline & 97 & 1.8 & 1.9 & 1.8 & 1.8 \\
\hline
\end{tabular}


An analysis of varlance was performed to test for significant differences among $\bar{d}$ values. No significant difference $(\alpha=0.05)$ was found among $\bar{d}$ values of sample size 100 to 400 for any of the stations during the fall or the spring. Therefore, a sample size of 100 was chosen as the optimum number of Individuals to count and was used throughout the remainder of the study.

\section{Specles Diversity}

Species diversity, $\bar{d}$, tended to increase downstream during all seasons except late summer (F1g. 8). Duncan's New Multiple Range Test was used to determine differences among stations for each season. In fall, minimum diversity was measured at Station 17 and maximum diversity at Station 97 . Station 4 and 44 were not significantly different from each other, but were different from the other stations $(\alpha=0.05)$.

The lowest diversity values measured in the study were recorded at Station 4 and 17 in winter (FIg. 8). Low values at these stations were due to large concentrations of Euglena virldis which on several sampling dates was the only species collected. Diversity was considerably greater at downstream stations in winter (F1g, 8). The diversity pattern in spring was simflar to the winter pattern, except $\bar{d}$ was greater at Station 4 and 17 in spring. Also, values at Station 17 and 44 were not signifIcantly different from each other in spring (Table IX). Few Individuals of Euglena viridis were present at the two upstream stations in the spring.

In summer Station 44 and 97 were not significantly different from each other (Table IX) but were slgnificantly greater than Station 17 


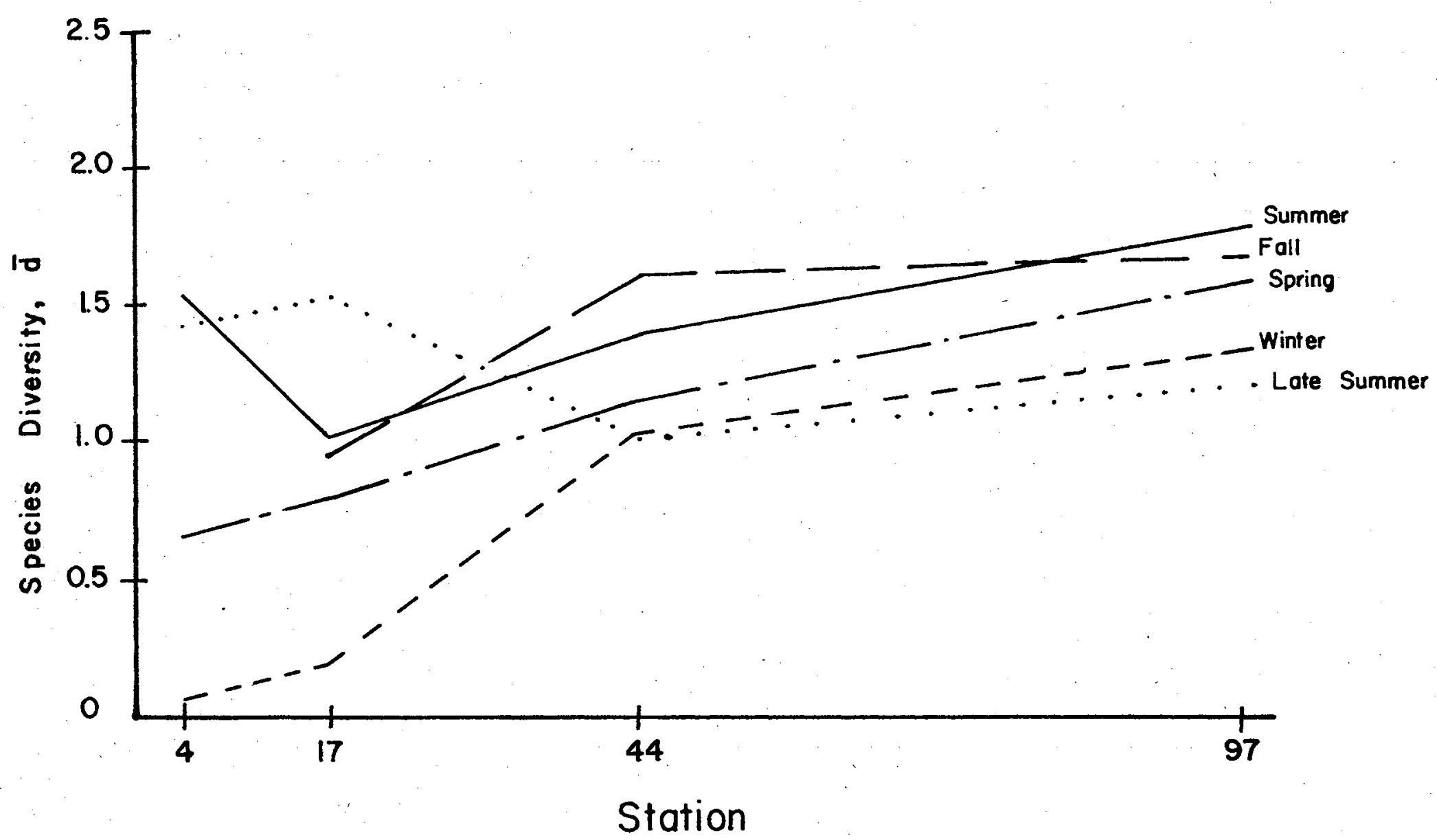

Figure 8. Longitudinal Varlation of Species Diversity in Skeleton Creek for the Five Seasons 
TABLE IX

COMPARISON OF $\bar{d}$ VALUES BY DUNCAN'S NEW MULTIPLE RANGE TEST WITH STATIONS RANKED FROM LOWEST TO HIGHEST DIVERSITY*

Fall

Station

17

$44 \quad 4$

97

Winter

Station

4

17

44

97

$=$

Spring

Station

4

17

44

97

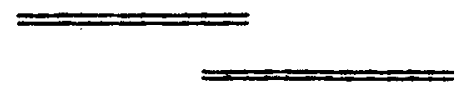

Summer

Station

17

44

97

$\longrightarrow$

Late Summer

Station

44

97

4

17

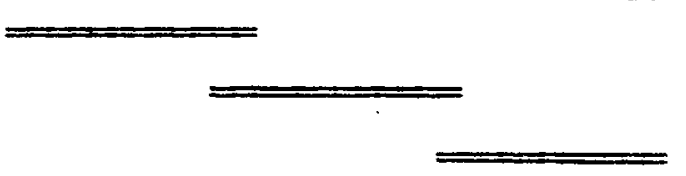

*Stations underscored by the same line are not judged to be significantly different $(\alpha=0.05)$. 
(Table IX). An Insufficient number of samples were collected at Station 4 to enable statistical treatment of this station.

The late summer period differed from the general pattern of increased diversity downstream. Values of $\bar{d}$ at the two upstream stations exceeded those at the two downstream stations (F1g. 8 and Table IX). This varlation possibly was brought about by high stream flow Immediately preceding the exposure perlod. High stream flow would tend to bring about an uniform distribution of nutrients as well as organisms.

W11hm and Dorris (1968) have reviewed the application of species diversity of benthic macroinvertebrates in determining degrees of pollution. They found values of $\bar{d}$ to be less than one in artas of hedy pollution, between one and three in areas of moderate pollution, and values exceeding three in clean water. Staub et al. (1970) determined $\bar{d}$ on phytoplankton in various streams recelving domestic and Industrial wastes in the vicinity of Memphis and Shelby Counties, Tennessee. They reported $\bar{d}$ of less than one in areas of severe pollution, from one to two in areas of moderate pollution, from two to three in areas of $11 \mathrm{ght}$ pollution, and values above three in clean water zones. A comparison of $\bar{d}$ values of periphyton obtained from Skeleton Creek with the criteria given by WIIhm and Dorris (1968) and Staub et al. (1970) Indicates upstream stations to be in areas of heavy pollution while downstream stations to be in areas of moderate pollution. Although clean water zones in Skeleton Creek were not indicated by $\bar{d}$ values of periphyton, longltudinal 1mprovement in water quallty downstream was suggested by $\overline{\mathrm{d}}$ values. 


\section{P1gment D1versity}

Margalef (1968) discussed a plgment diversity Index based on the rat1o of the absorbance of $90 \%$ acetone extract at $430 \mathrm{~nm}$ and $665 \mathrm{~nm}$, $\mathrm{D}_{430} / \mathrm{D}_{665^{\circ}}$. P1gment diversity has been related to nutrients and aging. In the event of a sudden increase in nutrients, chlorophy 11 a increases at a much greater rate than other plgments and this results in a reduced index. Margalef found the rat1o to be lowest in young, growing populations and highest in old, stable populations.

Plgmant diversity was calculated only for the winter and summer as these were the only seasons in which a sufficlent number of samples were collected. TIme had little effect on plgment diversity during the winter (F1g. 9) and summer (FIg, 10), Plgment diversity increased slightly during colonization and then leveled off. Longltudinal varlation in plgment diversity was slight during the winter and summer (FIg, 11),

In the present study, pigment diversity ranged from 1.42 to 2.36 . W11hm and Long (1969) found no effect on plgment diversity attributable to nutrients or time in microcosms. They reported values of two to three in their study. Knuds on (1970) reported mean phytoplankt on pigment diversity values of 2.34 and 2.41 in turbid ponds and values of 2.83 and 3.21 in clear ponds. Kehde (1970) reported values of 2.1 to 3.8 for periphyton in an artificlal stream with grazers and values of 1.9 to 3.8 with no grazers.

The lack of an 1ncrease in plgment diversity over time or distance downstream in the present study was attributed to a lack of aging in periphyton communities of streams. Patrick (1954) reported that as soon as periphytic diatoms die they no longer adhere to a substrate. Thus as the underlying layers of the periphyton mat die, portions of 


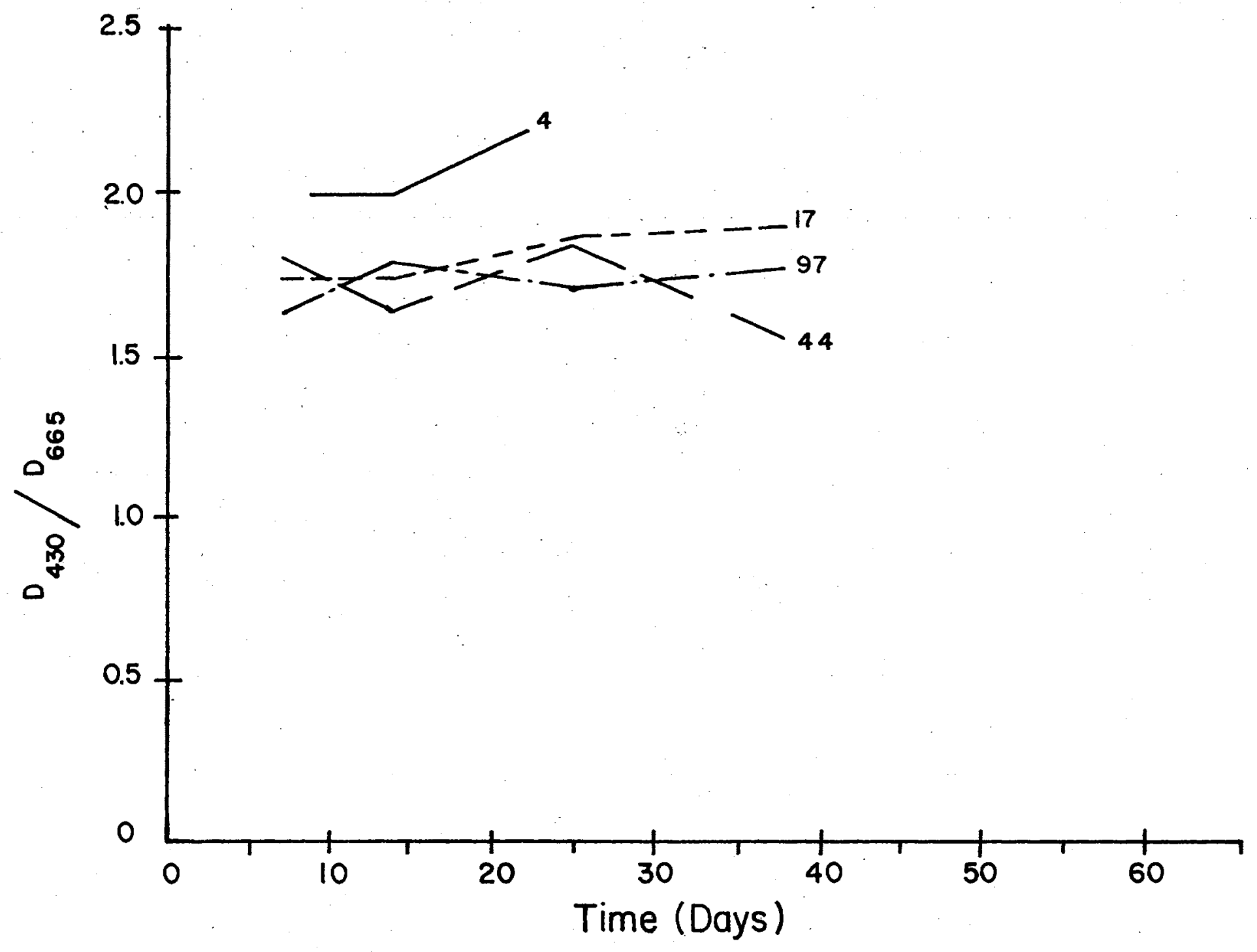

Figure 9. Temporal Variation in Pigment Diversity Ratio $D_{430} / D_{665}$ at the Four 


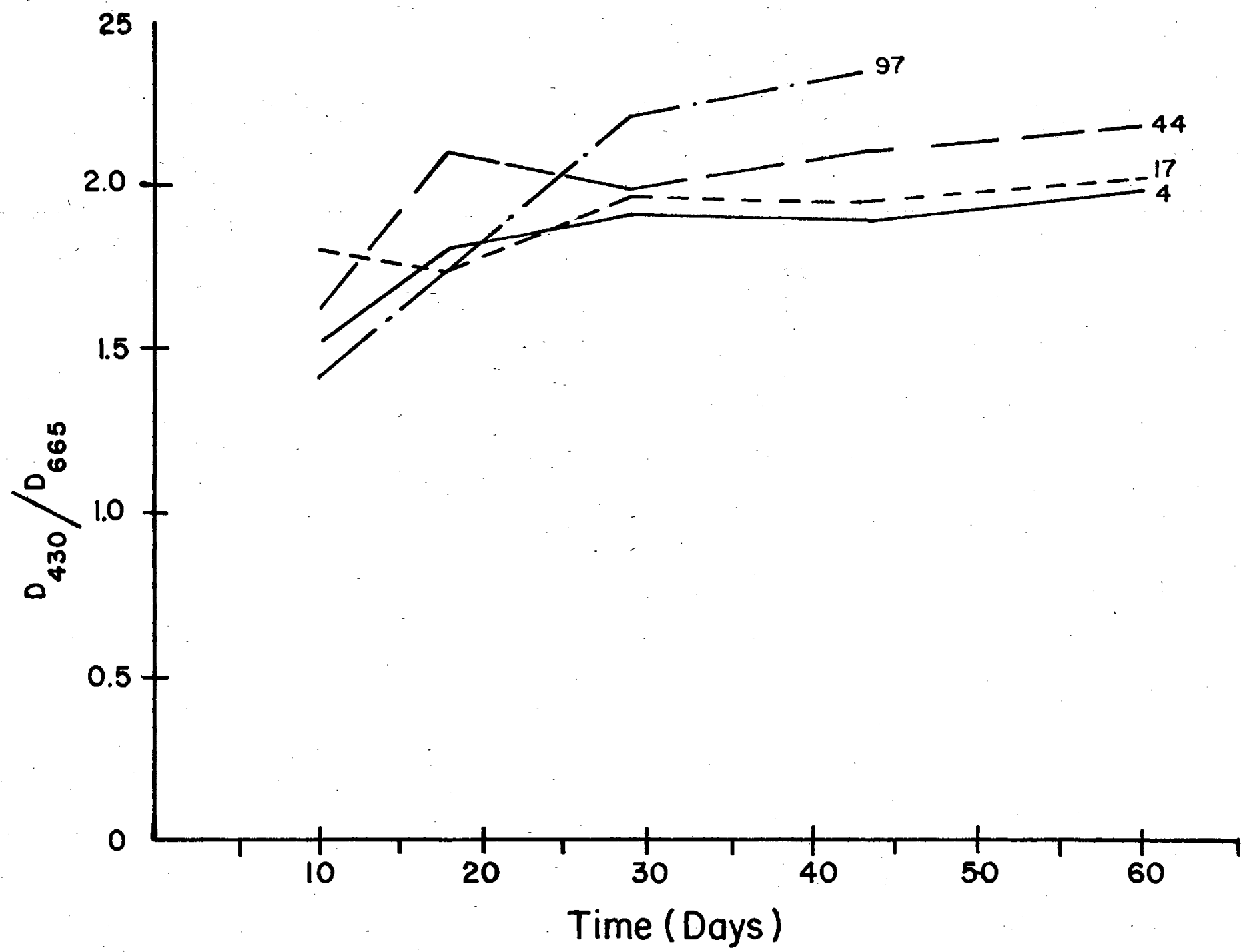

Figure 10. Temporal Variation in Pigment Diversity $\mathrm{D} / \mathrm{j} / 66$ at the Four statims in Skeleton Creek for the Sumer 40 Season 


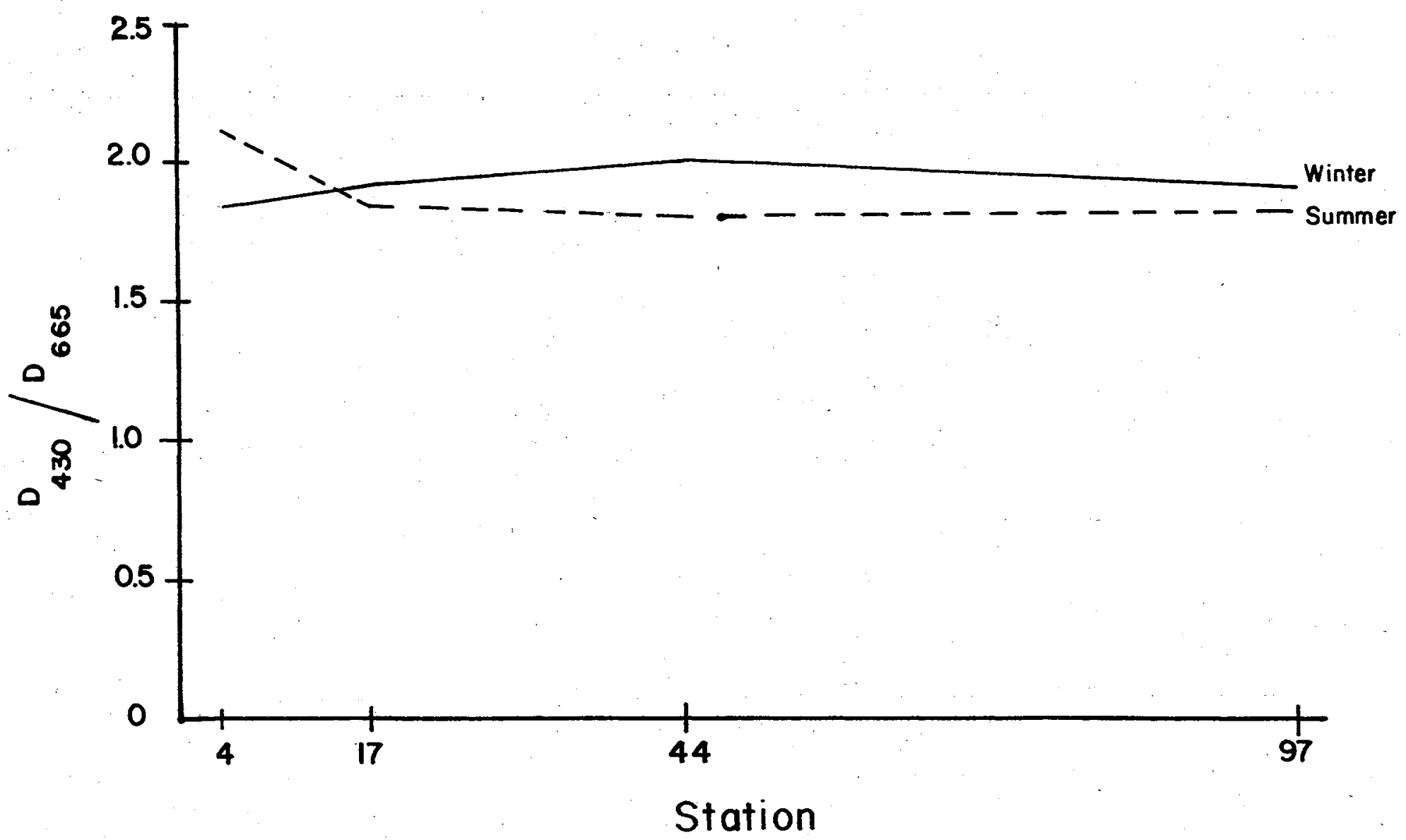

Figure 11. Spatial Varlation in Pigment Diversity $\Gamma_{430} \cdot{ }^{\prime 9} 665$ in Skeleton Creek 
the mat float away. Organisms that remain on the substrate are then capable of continued growth and reproduction at a rate determined by avallable nutrients and are not limited by apace. Thus, the community remains young and growing. This 18 oupported by the low pigment diversity $(<2.5)$ obtained during this study.

\section{Autotroph1c Index}

The autotroph1c Index proposed by Weber and MeFarland (1969) to determine water quality was applied to data from Skeleton Creak. The autotrophic index is the ratio of ash-free welght to chlorophyll $\underline{a}$ concentration. They stated that periphyton in unpolluted or olightly polluted water are mostly algae and have blomass to chlorophyll rat10s slmilar to those reported for algal cultures. As the level of organic pollution increases, the algae are replaced by filamentous bacteria and other non-chlorophyllous organism resulting in an increase in the blomass to chlorophyll ratio.

The mean seasonal autotrophic index tended to increase downstream in Skeleton Creek (Table X)。 However, Duncan's New Multiple Range Test did not Indicate a significant difference $(\alpha=0.05)$ among stations during the winter or summer. During the late summer, Station 17 was significantly different from Station 97 . Other stations were not different.

Autotrophic indices from Skeleton Creek are comparable with those found in unpolluted waters, algal cultures, and artificlal streams (Table XI). H1ghest mean seasonal values in Skeleton Creek are much lower than those reported for a polluted river (Weber and McFarland, 1969). 
TABLE X

MEAN SEASONAL VALUE OF THE AUTOTROPHIC INDEX FOR THREE SEASONS IN SKELETON CREEK, OKLAHOMA

\begin{tabular}{llllll}
\hline \multirow{2}{*}{ Exposure Period } & \multicolumn{4}{c}{ Station } \\
\cline { 2 - 5 } & 4 & 17 & 44 & 97 \\
\hline $\begin{array}{l}\text { Winter } \\
\vdots \\
\text { Summer }\end{array}$ & 151 & 103 & 176 & 315 \\
Late Summer & 117 & 103 & 154 & 292 \\
\hline
\end{tabular}


TABLE XI

AUTOTROPHIC INDEX CALCULATED FROM DATA

IN THE LITERATURE

\begin{tabular}{|c|c|c|}
\hline Investigator & Habitat & $\begin{array}{l}\text { Autot rophic } \\
\text { Index }\end{array}$ \\
\hline Myers, J. and W. A. Kratz, 1955 & Algal culture & 55 \\
\hline Parsons, T. R., 1961 & Algal culture & 70 \\
\hline Parsons, T. R. et al., 1961 & Algal culture & 96 \\
\hline Steemann Nielsen, E., 1961 & Algal culture & 45 \\
\hline Kehde, P. M., 1970 & $\begin{array}{l}\text { Artificial stream } \\
\text { with grazers }\end{array}$ & 470 \\
\hline Kehde, P. M., 1970 & $\begin{array}{l}\text { Artificial stream } \\
\text { without grazers }\end{array}$ & 720 \\
\hline McInt1re, C. D., 1968 & $\begin{array}{l}\text { Artificial streams } \\
\text { (Light intensity- } \\
\text { current) } \\
(150-0) \\
(150-14) \\
(150-35) \\
(700-0) \\
(700-14) \\
(700-35)\end{array}$ & $\begin{array}{l}267 \\
123 \\
127 \\
324 \\
204 \\
212\end{array}$ \\
\hline $\begin{array}{l}\text { Weber, C. I. and B. H. McFarland, } \\
1969\end{array}$ & $\begin{array}{l}\text { Unpolluted river } \\
\text { Polluted river }\end{array}$ & $\begin{array}{r}177 \\
1,019\end{array}$ \\
\hline
\end{tabular}


In the present study, productivity and secles diversity Indicate an Improvement in water quallty downstream from the pollution outfalls while no improvement downstream is shown by the autotrophic index. Additional work is needed to determine the effects of pollution on the autotrophic index. 


\section{CHAPTER V}

\section{SUMMARY}

1. The objectives of the study were to measure spatial and temporal varlation in productivity of the periphyton community, to relate species diversity and plgment diversity to levels of productivity and degrees of pollution, and to evaluate the autotroph1c Index as a method of characterla1ng water quality. Skeleton Creek, Oklahome, a stream recelving domestic and oll refinery wastes was sudied from October, 1967 to October, 1968.

2. Four stations selected for simflarity of light, depth, and current were numbered according to distance downstream from the confluence of Boggy Creek.

3. The study was dividad Into f1ve exposure perfods, each approximately 2 months in duration. Samples were collected at 3 to 7 day-intervals at each station for each exposure period.

4. Artificial substrata were used to sample the periphyton community. Th1rty-s1x Plex1glas plates each with an exposed surface area of $1 \mathrm{dm}^{2}$ were attached with bolts and wing nuts to floating redwood rafts. Plates were removed at 3 to 7 day 1ntervals to provide exposure times of increasing duration.

5. Maximum water temperature was $33 \mathrm{C}$ in July. Ice covered all stations in December. The pH was consistently alkaline at all stations. 
L1ttlo geasonal variation in $\mathrm{pH}$ was ovident. Dissolved oxygan as determined by daytime grab samples were higher at Station 4 and 97 with lower values at Station 17 and 44 . Alkalinity was due primarily to bicarbonate as phenolphthalein alkalinfty was detected only on two occasions. Light transmission decreased downstream except in winter. Highest 11ght transmission occurred during the winter when rainfal1 totaled only $4.1 \mathrm{~cm}$. Conductivity was highest upstream.

6. A discontinuous Iinear regrese1on model was devaloped to analyze growth curves of perlphyton. Colonization, acceleration, and asymptot1c phases of the growth curves were recognized. The slope of the regression line fitted to the acceleration phase of growth was used to estimate productivity.

7. In general, productivity decreased downstream from the pollution outfalls. Higher upstream productivity was due to high nutrlent levels resulting from the breakdown of sewage. Reduced productivity downstream Indicated an improvement in water quality.

8. Zero slope was malntained during the asymptotic phase of growth as increases in biomass were balanced by sloughing and grazing. 9. The ratio of net productivity to blomass did not indicate spatial or temporal successional stages in the perlphyton communtty. 10. Adequacy of sample size was determined by counting 1,000 Individuals from each of four samples from each station for the fall and spring. Graphic evaluation on pooled samples from size 100 to 1,000 did not Indicate a difference. No significant difference was found In Independent samples of s1ze 100, 200, 300, or 400 for the fall or spring. Therefore, 100 individuals were considered as an adequate sample slze. 
11. Twenty-two taxa of alga ware 1dentifled from skeleton Creek. Diatoms dominated the flora except at Station 4 and 17 during the winter when Euglene v1r1d1e was the most abundant.

12. Species diversity increased downstrem from the pollution outfalls. This Increase indicates a more varled periphyton communty and an 1mprovement in water quality。

13. P1gment divera1ty exhlb1ted 11ttle spatial or tamporal var1at1on. The lack of varlation in plgmant diveralty wa due to the perlphyton communty ramalning young and growing due to losses by sloughing. A continually young and growtng comming was further suggested by low p1gment divers1ty $(<2,5)$.

14. The autotrophic index applied to data from Skeleton Creek did not indicate an improvement in water quality downstreama No significant difference In this index was found during the winter or summer. Differences in the late summer did not indicate an improvement in water quality downstream from the pollution outfalls. Additional work is needed to determine the effects of pollution on the autotrophic index. 


\section{LITERATURE CITED}

American Public Health Association. 1960. Standard Methods for the Examination of Water and Waote Water. 11th ed. Amer. Public Health Assoc. New York. 626 p.

Banse, K. and G. C. Anderson. 1967. Computation of chlorophy11 concentrations from spectrophotometric readings. Limol. and Oceanog. 12:696-697.

Baumgardner, R. K. 1966. Oxygen balance In a stream receiving domestic and oll refinery effluents. Ph.D. Thesis. Okla. State Univ. $70 \mathrm{p}$.

Blum, J. L. 1956. The ecology of river algae. Bot. Rev. 22:291340 .

Castenholz; R. W. 1961. An evaluation of a submerged glass method of estimating production of attached algae. Verh. Internat. Verein. Limol. 14:155-159.

Cooke, W. B. 1956. Colonization of artificlal bare areas by microorganisms. Bot. Rev. $22: 613-638$.

Cooper, J. M. and J. L. Wilhm. 1970. Longltudinal variation of periphyton productivity in Skeleton Creek, Oklahoma. Proc. Okla. Acad. Sc1. $49: 19-22$.

Dickman, M. D. 1968. The effect of grazing by tadpoles on the structure of a periphyton community. Ecology. 49:1188-1190.

Flsher, R. A., A. S. Corbet, and C. B. Wllliams. 1943. The relation between the number of species and the number of individuals in a random sample of an animal population. J. Anim. Ecol. $12: 42-58$.

Foerster, J. W. and H. E. Schlichting. 1965. Phyco-periphyton in an ollgotrophic lake. Trans. Amer. Micros. Soc. 84(4):485-502.

Galloway, H. M. 1960. Soll survey of Logan County, Oklahoma. U. S. Dept. of Agr1. Soll Conserv. Serv. 60 p.

Gleason, H. A. 1922. On the relation between spectes and area. Ecology. 3:156-162.

Gray, F. and H. M. Galloway. 1959. Soll of Oklahoma. Okla. State Un1v., Agr1. Exp. Sta., M1sc. Publ. MP-56. 65 p. 
Grezenda, A. R. and M. L. Brehmer. 1960. A quant1tat1ve mothod for the collection and measurement of stream periphyton. "Ilmnol. and Oceanog. 5:190-194.

Grezenda, A. Ro, R, C. Ball, and N, R, Kevern. 1968, Prlmary production, energetics, and nutrient ut1lization in a warm-water stream. Tech. Rep. No, 2. Red Cedar R1ver Serfes.

Horton, R。 E. 1945. Eroslonal development of streams and the1r dralnage basins. Geol. Amer。Bull。 56:275-370.

Hynes, H. B. N。 1966. The blology of polluted waters. Liverpool UnIv. Press. L1verpool. $202 \mathrm{p}$.

Kehde, P. M. 1970. The effect of grazing by sma1ls on community structure of per1phyton in laboratory streams. M. S. Thes 1s. Okla。State UnIv. $34 \mathrm{p}$ 。

Kevern, N. Ro, J. L. W1lhm, and G. M. Van Dyne. 1966. Use of artiflclal substrata to estimate the productivity of periphyton. LImnol. and Oceanog. 11:499-502.

Kn1ght, A。, $R_{\circ} C_{\circ}$ Ball, and $F_{a} F_{0}$ Hooper, 1962, Some estlmates of primary production rates in Michigan ponds. Papers Mich. Acad. Sc1., Arts, and Letters.

Knudson, V。 Aa 1970. Community structure of plankton in clear and turbld ponds。 $\mathrm{Ph}_{\circ} \mathrm{D}$. Thesls。 Okla。State Un1v. $106 \mathrm{p}$ 。

Kochslek, K. A. 1970. Communlty structure of net zooplankton and related physicochemlcal 11mnology In Keystone Reservo1r, Oklahoma. $\mathrm{Ph}, \mathrm{D}$. Thesis. Okla.State UnIv。 $58 \mathrm{p}$.

Margalef, R. 1956. Information y diversidad esplcfica en las comfnudades de organlsmos. Inv. Presq. 3:99-106.

Margalef, R. 1958. Temporal succession and spatial heterogenelty In phytoplankton. Perspectives In Marine Blology. Univ。 of Cal1f, Press. Berkeley and Los Angles. 111 p.

Margalef, R。 1968. Perspectives in Ecological Theory. Un1v。 of ChIcago Press. Ch1cago. $111 \mathrm{p}$.

McConnel1, W. Jo and W. F。 Sigler. 1959. Chlorophyll and productivity In a mountain river. Limnol, and Oceanog. 4:335-351.

McIntire, C. Do 1968. Structural character1st1cs of benthic algal communties in laboratory streams. Ecology. 49:520-537.

Menhintck, E。 F。 1964. A comparison of some species-individuals diversity Indices applied to amples of fleld insects. Ecology. $45: 859-861$ 。 
Myers, J. and W. A. Kratz. 1955. Relatione between pigment content and photosynthet1c character1otice in a blue-grean alga. Jour. Gen. Phys101. $39: 11-22$.

Odum, H. T. 1956. Primary production of flowing waters. Limnol. and Oceanog. 1:102-117.

Parsons, T. R. 1961. On the pigment composition of elieven species of marlne phytoplankton. Jour. F1sh. Res. Board Can. 18:10171025 .

Parsons, T. Ro, Ko Stephens, and Jo $D_{0} H_{0}$ Strickland 1961。 On the chemical composition of eleven specles of marlne phytoplankton. Jour. Flsh. Res. Board Can. 18:1001-1016.

Parsons, T. R. and Jo D. H. Strickland. 1963. D1scussion of spectrophotometr1c determination of merine plant p1gments, with revised equations for ascertaining chlorophylls and carotenolds. Jour. Mar. Res。 21:155-163.

Patrick, R. 1968. The structure of diatom communfties in simflar conditions. Amer. Nat. 102:173-183.

Patrick, R., M. Ho Hohn, and J。 Ho Wallace, 1954. A new method for determining the pattern of the dlatom flora. Not. Nat. Acad. Nat. Sc1. $259: 1-12$.

Patten, B. C. 1962. Species diversity in net phytoplankton of Rar1tan Bay. J。 Mar. Res. 20:57-75.

Preston, F. W. 1948. The commonness and rarity of specles. Ecology. $29: 254-283$ 。

Robins, $C$, and $R_{a} W_{\text {a }}$ Crawford。 1954. A short accurate method for estimating the volume of stream flow. J. Wildf. Manag. $18: 363-369$.

Round, F. E. 1964。 The ecology of benth1c algae. In D. F. Jackson (ed.), Algae and Man. Plenum Press. New York. 138-184 pp.

Sladeckova, A. 1962. Ilmological Investigation methods for the periphyton ("Aufwuchs") communtty。 Bot, Rev. 28:287-350.

Staubl, Ro, J。W. Appling, A. M. Hofstetter, and I。 J. Hass. 1970. The effect of Industrial waste of Memphis and Shelby County on primary plankton producers. Blosclence. 20:905-912.

Steele, R. G. D. and J。H. Torrle. 1960. Principles and procedures of stat1st1cs. McGraw-H111 Book Company, Inc New York. 481 p.

Steemann Nielsen, E. 1961. Chlorophyl1 concentration and the rate of photosynthesis in Chlore11a vulgaris. P1. Physiol. $14: 867-868$. 
U. S. Department of Commerce. 1967. Cl1matolog1cal data. Oklahoma. $76: 207$.

U. S. Dapartment of Commerce. 1968. Climatological data. Oklahoma. $77: 215$.

U. S. Department of Inter1or, Geologtcal Survey, Water Resourees D1vision. 1968. Water wources duta for Okluhome Part I. Surface Water Recorda.

Waters, T. R. 1961. Notes on the chlorophyll method of estimating the photsynthet1c capacity of tream periphyton. Limnol. and Oceanog. $6: 486-488$.

Weber, Co Io and B。 Ho McFarland. 1969.: Pertphyton biomass-chlorophy 11 rat 1o as an index of water qual1ty." Unpublished.

Wetzel, R. G。 1964。 A comparative study of the primary productivity of higher aquat1c plants, periphyton, and phytoplankton in a large, shallow lake. Intern. Rev。 qes. Hydrob 101. 49:1-64.

Wetzel, R. G. 1965. Technfques and problems of primary productivity measurements in higher aquatlc plants and periphyton. In $C_{0} R_{0}$ Goldman (ed.), Primary Productivity in Aquatic Environments. Mem. Inst. Ital. Idrob1ol, 18 Supp1。 Untvo of Calif. Press. Berkeley。249-267 pp.

Wetze1, R. Go 1969。 Primary production rates from changes in biomast

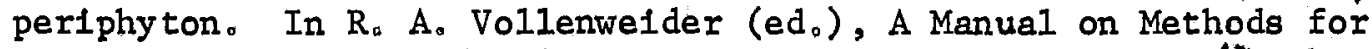
Measuring Primary Production in Aquatic Environments. Harfopook No. 12. International Blological Programme. 7 Marylebone Road。 London. NW 1. $213 \mathrm{p}$.

Wetze1, R。 Ga and Do F。 Westlake. 1969. Sampling techniques and methods for estimating quantity and quality of biomass-periphyton. In R. A. Vollenwider (edo), A Manual on Methods for Measuring Primary Production In Aquatic Environments Handbook No. 12. International Biological Programme. 7 Marylebone Road. London. NW 1. $213 \mathrm{p}$ 。

Whitford, I. A. 1960. The current effect and growth of fresh-water algae。Trans。Aner。Microse.Soc。 $79: 302-309$ 。

Whitford, I. A。 and Go Jo Schumacher. 1961。 Effect of current on mineral uptake and resplration by a fresh-water algae. Iimol。 and Oceanog. 6:423-425。

W11hm, Jo Lo and $T_{0} C_{0}$ Dorr1s. 1966. Species diversity of benthic macro-invertebrates in a stream recelving domestic and o11 refinery effluents. Amer。Mid1. Natur. 76:427-449. 
W1 Ihm, J. L. and T. C. Dorris. 1968. Blologlcal parameterg for water quality. Blosclence, 18:477-481.

W1 hm, J. L. and J. Long. 1969. Succession In algal mat communties at three nutrient levela. Ecology. 50:645-652.

Young, 0. A. 1945. A 11mnological invertigation of periphyton in Douglas Lake, M1ch1gan. Trans.Amar. Microsc. Soc. 64:1-20.

Yount, J. 1956. Factors that control. opecies numbers in Silver Springs, Flor1de. LImnol, and Oceanog. 1:286-295. 


\section{VITA \\ James M1ckey Cooper \\ Candidate for the Degree of \\ Doctor of Ph1losophy}

Thesis: SPATIAL AND TEMPORAL VARIATION IN PRODUCTIVITY, SPECIES DIVERSITY, AND PIGMENT DIVERSITY OF PERIPHYTON IN A STREAM RECEIVING DOMESTIC AND OIL REFINERY EFFLUENTS

Major Fleld: Botany

Biographical:

Personal Data: Born near Centrahoma, Oklahoma, March 29, 1940 , son of Sonnte and Edna Sawyers Cooper.

Education: Graduated from Tupelo High School, Tupelo, Oklahoma, In 1958; recelved the Bachelor of Sclence degree from East Central State College, Ada, Oklahoma in August, 1962; recelved the Master of Sclence degree in Botany from Oklahoma state University, Stillwater, Oklahoma, in May, 1965; completed requirements for the Doctor of Philosophy. degree in May, 1972, at Oklahoma State University.

Professional Experience: Graduate Teaching Assistant, Oklahoma State University, 1962-1964; Instructor of Blology, Cameron College, Lawton, Oklahoma, 1964-1969; Graduate Teaching Assistant, University of Montana Blological Station, Missoula, Montana, Sumer, 1965; National Science Foundation Research Part1clpant, Unlversity of Oklahoma Blological Station, Summer, 1966; Assistant Professor of Biology, Cameron College, 1969-1971.

Member: Ph1 Sigma Soclety, Associate Member of Sigma X1, Southwestern Association of Naturallsts, and Oklahoma Academy of Sclence. 